\title{
EVALUATION OF EXCAVATOR TECHNOLOGIES: APPLICATION OF DATA FUSION BASED MULTIMOORA METHODS
}

\author{
Serkan ALTUNTAS ${ }^{\text {a }}$, Turkay DERELI ${ }^{\text {b, c }}$, Mustafa Kemal YILMAZ $^{\text {d }}$ \\ ${ }^{a}$ Department of Industrial Engineering, Yildiz Technical University, 34349 Istanbul, Turkey \\ ${ }^{b}$ Office of the President, Iskenderun Technical University, 31200 Iskenderun, Turkey \\ ${ }^{c}$ Department of Industrial Engineering, Gaziantep University, 27310 Gaziantep, Turkey \\ ${ }^{d}$ Department of Business, Ondokuz Mayls University, 55270 Samsun, Turkey
}

Received 03 Dec 2014; accepted 20 May 2015

\begin{abstract}
Excavators are quite expensive vehicles. Therefore, there may be huge losses for decision makers if a wrong decision is made during the purchasing process. A good evaluation of excavator alternatives both reduces costs and increases the benefits the excavator for the purchaser. The aim of this study is to prioritise excavator technologies to help decision makers during the purchasing process and to apply three different "data fusion methods" instead of the "theory of dominance" of the original MULTIMOORA method. The MULTIMOORA method is composed of three methods, namely: the ratio analysis as a part of MOORA, Reference Point Theory (the reference point approach as a part of MOORA) and the Full Multiplicative Form. It is used to prioritise excavator technologies in this study. The MULTIMOORA method combines three results obtained from these three methods using the theory of dominance. Dominance directed graph, Rank position method and Borda count method as data fusion methods are also used to combine these three results instead of the "theory of dominance". The results from this study show that there is no difference between the data fusion methods and the MULTIMOORA method can be applied to technology evaluation of the excavator alternatives successfully.
\end{abstract}

Keywords: excavator technologies, MULTIMOORA, dominance directed graph, rank position method, Borda count method, decision making.

\section{Introduction}

Machinery and equipment selection is essential to firms in order to be successful in a business environment. The selection of unsuitable machinery negatively affects all aspects of business performance. This also leads to failure in meeting the requirements of the customers in terms of quality, time and cost. Therefore, the selection of the most suitable machine among alternatives increases firms' competitiveness.

The purchasing function has received considerable attention because it is vital in determining the survival and profitability of businesses (Bayazit et al. 2006). The process of buying a machine is complex and consists of many stages. In this process, different business managers try to determine the machine which will be bought with respect to certain criteria and to influence the selection decision based on their own selection priorities. They also consider different evaluation criteria with respect to whether they are buying a machine for the first time.

Selecting the best excavator technologies (in terms of criteria considered) is not easy since there are many criteria, and they can be quantitative or qualitative, with equipment characteristics judged as beneficial and non- beneficial. The aim of the excavator selection process is to choose the option that reduces costs and increases benefits compared with alternative excavators.

In Turkey, ongoing urban renewal is increasing the demand for excavation equipment, and is making choosing the right equipment all the more important. Both domestic and foreign investors have begun to invest in the heavy equipment sector in Turkey due to its anticipated growth (Dunya newspaper 2014). On a project scale, the selection of the most suitable excavator - an essential vehicle in urban renewal - is important in order to obtain maximum efficiency and effectiveness. According to the Industry Directorate-General study (2010), in Turkey, 11,500 units of business machinery were sold in 2007, of which 3,830 were excavators.

Inappropriate excavator selection increases costs and decreases the benefits of the excavator for decision makers. This paper presents a real-life case study on the successful application of the MULTIMORA method for the selection of excavator technologies. The MULTIMORA method provides evaluation of technology alternatives from multiple perspectives. The major contribution of this paper is to extend different data fusion methods,

Corresponding author: Serkan Altuntas

E-mails:serkan@yildiz.edu.tr; saltuntas2@gmail.com 
namely dominance directed graph, rank position method and the Borda count method, in conjunction with the MULTIMOORA method for excavator selection.

The MULTIMOORA method was introduced by Brauers and Zavadskas (2010). This method prioritises alternatives easily in the presence of cost and benefit criteria. It is composed of three methods: the ratio analysis as a part of MOORA, Reference Point Theory (the reference point approach as a part of MOORA) and the Full Multiplicative Form. The MULTIMOORA method combines three results obtained from these three methods using the theory of dominance. Instead of the theory of dominance in the original MULTIMOORA method, the dominance directed graph, rank position method and the Borda count method are also used to combine these three results in this paper.

\section{Literature review}

The research considered different criteria in the literature for the selection of excavator technologies. Among them, Cebesoy (1999) took into account bucket size, engine power, weight, breakout force, crowd force, speed, cut height, digging height, and digging depth for excavator selection using an improved quality comparison method. Soykan (2009) selected an excavator using conjoint analysis and considered walking system, scoop movement, catalogue language, scoop storage, and working load as criteria. In addition to these studies, Aykul et al. (2007) selected hydraulic excavator/truck and surface miner/ truck combinations for highly selective excavation surface coal mining. Kirmanli and Ercelebi (2009) also developed an expert system for hydraulic excavators and truck selection in surface mining.

The MULTIMOORA method has been successfully applied in many fields, such as evaluation of the economy of the Belgian regions (Brauers, Ginevičius 2010), project management (Brauers, Zavadskas 2010; Brauers 2012), evaluation of Lithuania's position in the European Union (Baležentis et al. 2010), ranking heating losses in a building (Kracka et al. 2010), the selection of bank loans (Brauers, Zavadskas 2011a), selection of building elements for renovations important for energy savings (Brauers et al. 2012), evaluation of the construction sector in twenty European countries (Brauers et al. 2013), evaluation of public debt risk (Stankevičienè, Rosov 2013), ranking climate change mitigation policies in Lithuania (Streimikiene, Balezentis 2013), evaluation of the financial stability of commercial banks (Brauers et al. 2014) and special education and rehabilitation center selection (Özçelik et al. 2014). In addition to these studies, Brauers and Zavadskas (2012) provided information about the robustness of the MULTIMOORA method. A survey of the applications of the MULTIMOORA method can be found in T. Baležentis and A. Baležentis (2014).

The MULTIMOORA method is composed of the ratio analysis as a part of MOORA, Reference Point Theory (the reference point approach as part of MOORA) and the Full Multiplicative Form. The MOORA method is applied in many different fields, such as materials selection (Karande, Chakraborty 2012), privatisation in a transition economy (Brauers, Zavadskas 2006), evaluation of inner climate (Kalibatas, Turskis 2008), assessment of road design alternatives (Brauers et al. 2008a), contractors' ranking (Brauers et al. 2008b), assessment of regional development in Lithuania (Brauers et al. 2010), evaluating contractors' alternatives in the facilities sector in Lithuania (Brauers, Zavadskas 2009), robustness in regional development in Lithuania (Brauers, Ginevičius 2009), decision-making in the manufacturing environment (Chakraborty 2011) and parametric optimisation of the milling process (Gadakh 2011). Galetakis et al. (2015) developed an expert system for the prediction of the performance of bucket-wheel excavators. In some studies, researchers focused on equipment selection for excavators. For example, Morley et al. (2013) used discrete event simulation for excavator hauler fleet selection; Qunzhang et al. (2011) proposed analytical hierarchy method for monitoring the parameters selection of the hydraulic system of an excavator. Wang et al. (2009) proposed a combined simulation and analysis to compare the performance of excavator types.

The combination of the MULTIMOORA method and other methods has been extensively documented in the literature; for example, the combination of the MULTIMOORA method and data envelopment analysis for multi-criteria assessment and comparison of farming efficiency (T. Baležentis, A. Baležentis 2011a), the combination of the MULTIMOORA method and data envelopment analysis for assessing the efficiency of the Lithuanian transport sector (T. Baležentis, A. Baležentis 2011b), the combination of the MULTIMOORA method and grey set theory for robot selection (Datta et al. 2013) and the combination of the MULTIMOORA method and interval value grey number sets for CNC machine tool evaluation (Sahu et al. 2014). Liu et al. (2014) proposed interval 2-tuple linguistic MULTIMOORA method for health-care waste treatment technology selection.

In the literature, the usage of the MULTIMOORA method is generally preferred if the presence of quantitative criteria is known and there is a possibility to construct the decision matrix easily. However, in this paper, the excavator selection problem is solved by group decision makers and according to the quantitative and qualitative criteria of the MULTIMOORA method. In addition, this is the first study that extends the original MULTIMOORA method using different data fusion methods, namely, Dominance directed graph, Rank position method and Borda count method.

\section{Methods}

\subsection{MULTIMOORA}

The MULTIMOORA is a relatively new multi-criteria decision making method consisting of three parts: the ratio analysis as a part of MOORA, Reference Point Theory 


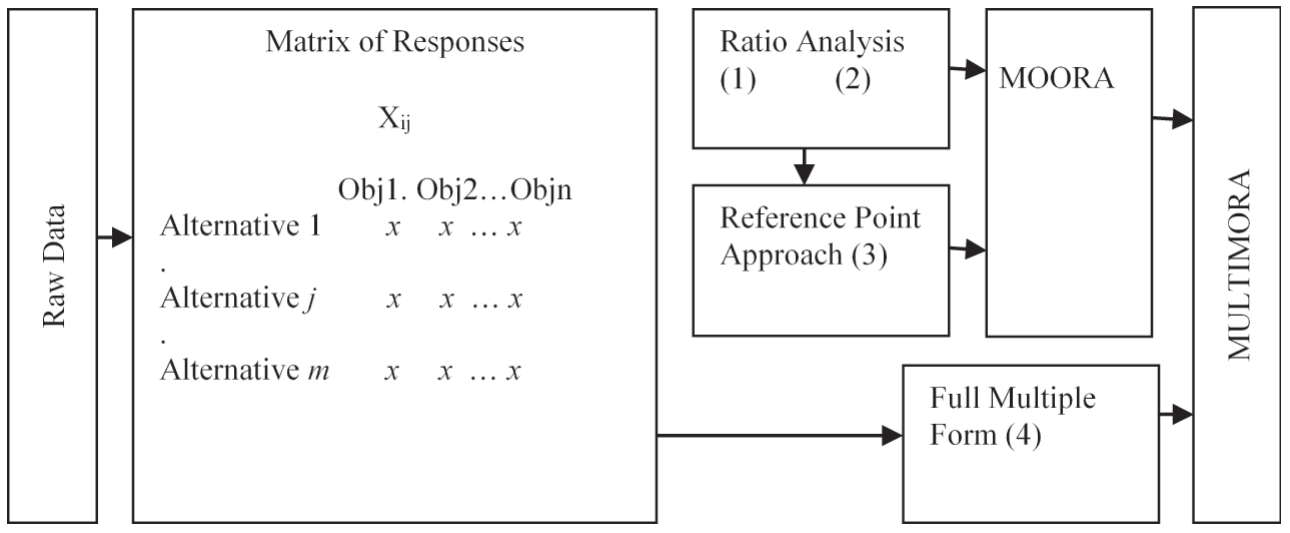

The number between brackets refers to the basic equation used for the related method. Details on the methods are given in the following.

Fig. 1. Diagram of MULTIMOORA (Brauers et al. 2012)

(the reference point approach as a part of MOORA) and the Full Multiplicative Form (T. Baležentis, A. Baležentis 2014). The MULTIMOORA method makes it a possible to increase the robustness of the results due to the aggregation of these approaches (Brauers, Zavadskas 2011b). In the MULTIMOORA method, the theory of dominance is proposed by Brauers and Zavadskas (2011a) to combine the results of these methods. Details on the theory of dominance can be found in Brauers and Zavadskas (2011a) and Brauers et al. (2012). The dominance directed graph, Rank position method and Borda count method are also used to obtain a ranking of alternatives. Figure 1 summarises the MULTIMOORA method.

\subsubsection{The ratio analysis as a part of MOORA}

The steps of the ratio analysis as a part of MOORA are given below in stepwise fashion.

Step 1: Construct the decision matrix of responses (see Fig. 1).

Step 2: Normalize the decision matrix by using Eqn (1):

$$
x_{i j}^{*}=\frac{x_{i j}}{\sqrt{\sum_{j=1}^{m} x_{i j}^{2}}},
$$

where: $x_{i j}$ - response of alternative $j$ on objective $i ; j=1$, $2, \ldots, m ; m$ is the number of alternatives; $i=1,2, \ldots, n$; $n$ is the number of objectives.

Step 3: Calculate the final preference by using Eqn (2):

$$
y_{i}^{*}=\sum_{i=1}^{g} x_{i j}^{*}-\sum_{i=g+1}^{n} x_{i j}^{*},
$$

where: $i=1,2, \ldots, g$ as the objectives to be maximized; $i=g+1, g+2, \ldots, n$ as the objectives to be minimized; $y_{j}^{*}-$ the final preference for $j^{\text {th }}$ alternative. Each alternative is sorted in descending order with respect to $y_{j}{ }^{*}$.

\subsubsection{The Reference Point Approach as a part of MOORA}

The Reference Point Approach as a part of MOORA includes three steps and the first two steps are the same steps as the ratio analysis as a part of MOORA. The steps of the reference point approach as a part of MOORA are given below in a stepwise manner.

Step 1: Construct the decision matrix which shows the matrix of responses (see Fig. 1).

Step 2: Normalize the decision matrix by using Eqn (1). Step 3: Calculate the reference point by using Eqn (3) and give a preference with respect to the result:

$$
Z_{i}=\min (j)\left\{\max (i)\left|r_{i}-x_{i j}{ }^{*}\right|\right\},
$$

where: $Z_{j}$ - the final preference for the $j^{\text {th }}$ alternative; $r_{i}$ - the $i^{t h}$ coordinate of the reference point in the normalized decision matrix.

If the objective should be maxima, we choose the highest value as $r_{i}$ for related objective. On the other hand, we choose the lowest value as $r_{i}$ for related objective, if the objective should be minimal. Herein, the lowest $Z_{i}$ value shows the best alternative, while the highest $Z_{i}$ value shows the worst alternative.

\subsubsection{The Full Multiplicative Form for Multi-Objectives}

The Full Multiplicative Form for Multi-Objectives includes two steps, the first of which is that same as the first step of MOORA (both Ratio Analysis and Reference Point Approach). The steps of the full multiplicative form for multi-objectives are given as follows in a stepwise manner.

Step 1: Construct the decision matrix of responses (see Fig. 1).

Step 2: Calculate the overall utilities $\left(U_{j}\right)$ by using Eqn (4):

$$
U_{j}=\prod_{i=1}^{n} x_{i j} .
$$


If some objectives are to be maximized and others are to be minimized, we combine these objectives by using Eqn (4'):

$$
U_{j}^{\prime}=\frac{A_{j}}{B_{j}} .
$$

$U_{j}^{\prime}$ shows the value of the utility of alternative $j$ with the objectives to be maximized and objectives to be minimized with:

$$
A_{j}=\prod_{g=1}^{i} X_{g j},
$$

$j=1,2, \ldots, m$ is the number of alternatives and $i$ is the number of objectives to be maximized with:

$$
B_{j}=\prod_{k=i+1}^{n} X_{k j}
$$

$n-i$ is the number of objectives to be minimized.

\subsection{Data fusion methods}

The aim of data fusion methods is to merge results obtained from the different resources. Data fusion methods are extensively used in the literature for the information retrieval system. However, in addition to utilising the theory of dominance proposed by Brauers and Zavadskas (2011a) in the original MULTIMOORA method, the dominance directed graph, the rank position method and the broad count method are also used in this study to merge the results of the ratio analysis part of MOORA, the reference point approach part of MOORA and the full multiplicative form for multi-objectives.

\subsubsection{The dominance directed graph}

The dominance directed graph is known as a tournaments because each ranking obtained from the three methods can be considered to be a tournament. In addition, each alternative (excavator technology) can also be considered a team. In the dominance directed graph, Team A can dominate Team B or vice versa, but not both. The vertex matrix $\left(\mathbf{M}=\left[m_{i j}\right]\right)$ of each tournament should be constructed. If Team A dominates Team B, $m_{A B}$ is equal to 1 , otherwise 0 . Matrix $M$ shows the dominance relation among alternatives for a tournament. Subsequently, $\mathrm{M}^{2}$ is calculated and then $A=M+M^{2}$. The row sums of $A$ show its preference. The highest value of the row sums is the best alternative, while the lowest value is the worst alternative. In this study, the sum of each row obtained by each method for each excavator technology is summed for the final ranking.

\subsubsection{The rank position method}

The rank position method, which is also named the reciprocal rank method, considers the current position of each alternative with respect to each method. The following formula shows the rank position score $(r)$ for each alternative, and is used to obtain final ranking. The highest value of the rank position score is the worst alternative and the lowest value is the best alternative:

$$
r\left(d_{i}\right)=1 /\left(\sum_{j} 1 / \text { position } d_{i j}\right) \text { for all }(j),
$$

$k$ - number of results obtained from the methods, $j=1$, $\ldots ., k ; p$ - number of alternatives, $i=1, \ldots ., p$.

In this paper, $k=3$ (the results of the ratio analysis part of MOORA, the reference point approach part of MOORA and the full multiplicative form for multi-objectives) and $p=13$ (the number of excavator technologies).

An example can be given to show how the rank position method works. There are only two possible ways, which equal to $\mathrm{k}$, to sort the alternatives with respect to their priorities. Each possible way is denoted A and B. There are four alternatives $(p)$, namely $x, y, z, t$. The ranking lists are given as follows:

$$
\begin{aligned}
& \mathrm{A}=(x, y, t, z) ; \\
& \mathrm{B}=(t, x, y, z) .
\end{aligned}
$$

The computation of rank position of each alternative is given as follows:

$$
\begin{aligned}
& r(x)=1 /(1+1 / 2)=0.67 ; \\
& r(y)=1 /(1 / 2+1 / 3)=1.2 ; \\
& r(z)=1 /(1 / 4+1 / 4)=2 ; \\
& r(t)=1 /(1 / 3+1)=0.75 .
\end{aligned}
$$

Hence, the final ranked list of the alternatives is: $x>t>y>z$.

\subsubsection{The broad count method}

The broad count method is a simple and effective method (Erp, Schomaker 2000) and does not require any training to combine the rankings (Ruta, Gabrys 2000). The number of alternatives is equal to the number of votes in the method. The highest ranked alternative (in a p-way vote) gets $p$ votes and each subsequent alternative gets one vote less (Nuray, Can 2006). The Broad Count (BC) value is calculated by summing the votes given to each alternative in each method. The final broad score is calculated by the aggregation of each of the individual scores, which denoted by BC( $i$ ) (Moreira 2011). BC( $i$ ) shows the BC value of $i^{\text {th }}$ alternative. The highest $\mathrm{BC}$ value is the best alternative and the lowest value is the worst alternative in the method. Some examples for the introduction of the method can be found in Nuray (2003), Nuray and Can (2006), Bozkur et al. (2007) and Moreira (2011).

The computation of broad count method is presented in the following by considering the previous small example:

$$
\begin{aligned}
& \mathrm{BC}(x)=4+3=7 ; \\
& \mathrm{BC}(y)=3+2=5 ; \\
& \mathrm{BC}(z)=1+1=2 ; \\
& \mathrm{BC}(t)=2+4=6 .
\end{aligned}
$$

Therefore, the final ranked list of the alternatives is $x>t>y>z$. Table 1 summarizes all methods. 
Table 1. A summary of all method

\begin{tabular}{|c|c|c|}
\hline No & Method & Formula \\
\hline 1 & $\begin{array}{l}\text { The Ratio Analysis as a part of MOORA } \\
\text { (as a first part of } \\
\text { the MULTIMOORA) }\end{array}$ & $y_{i}^{*}=\sum_{i=1}^{g} x_{i j}^{*}-\sum_{i=g+1}^{n} x_{i j}^{*}$ \\
\hline 2 & $\begin{array}{l}\text { The Reference Point Approach as a part of MOORA } \\
\text { (as a second part of the MULTIMOORA) }\end{array}$ & $Z_{i}=\min (j)\left\{\max (i)\left|r_{i}-x_{i j}{ }^{*}\right|\right\}$ \\
\hline 3 & $\begin{array}{l}\text { The Full Multiplicative Form for Multi-Objectives } \\
\text { (as a third part of the MULTIMOORA) }\end{array}$ & $U_{j}^{\prime}=\frac{A_{j}}{B_{j}}$ \\
\hline 4 & The dominance directed graph & $\mathrm{A}=\mathrm{M}+\mathrm{M}^{2}$ \\
\hline 5 & The rank position method & $r\left(d_{i}\right)=1 /\left(\sum_{j} 1 /\right.$ position $\left.d_{i j}\right)$ for all $(j)$ \\
\hline 6 & The broad count method & $\mathrm{BC}(i)$ \\
\hline
\end{tabular}

\section{Application of the proposed method for evaluat- ing excavator alternatives}

At the beginning of the study, the construction companies within Bayburt Trade and Industry Cooperation in Turkey were determined. Interviews were carried out with the heads of the companies, and one company was expected to buy an excavator in the near future. Decision makers in the company stated that they would purchase an excavator weighs about 25-30 tonnes with crawler. Subsequently, 13 alternatives meeting the requirements of the decision makers were identified from seven different brands. Then, the factors influencing the excavator choice were analysed through a review of the literature. To find criteria apart from those in the related literature concerning the excavator selection process, the opinions of marketing managers who work in excavator firms were surveyed via e-mail. Eleven quantitative criteria (five beneficial criteria and six non-beneficial criteria) and seven qualitative criteria (all of them beneficial) were determined for the excavator selection.

Some selection criteria were deemed to be missing from the catalogues for quantitative criteria. The sales representatives of the branches of all the brands were called to determine the missing quantitative criteria. A questionnaire was administered to the decision makers group with the aim of measuring their evaluations for qualitative criteria with regard to the 18 criteria and seven brands determined through the literature reviews and the interviews with the marketing managers. All studies up to that point included the stages of problem identification and organising the data. The data obtained subsequently were analysed by using the original MULTIMOORA method. In the final part of the study, alternatives were placed in order using the dominance directed graph, the rank position method, and the Borda count method adjusted MULTIMOORA methods. All these studies, including application, analysis and evaluation, are summarised in Figure 2. Figure 3 presents the hierarchical decision model for the evaluation of excavator technologies.

\subsection{Criteria}

In the literature, researchers use objective (quantitative) criteria only for examining excavator technologies. However, Chernatony and McDonald (2003) indicate that both objective and subjective issues have an impact on the decision makers. In addition, there may be some criteria that should be minimized, while others maximised. Therefore, we tried to determine the criteria affecting the excavator selection process based on the above mentioned lines. Firstly, some criteria were determined by reviewing the related literature. To find criteria apart from those in the related literature that affect the excavator selection process, an e-mail survey was conducted to gather the opinions of marketing managers who work in excavator firms. It should be noted that selected excavator firms are members of the Turkey Construction Machinery Manufacturers and Distributors Association. Finally, the literature review and interviews suggested 11 quantitative criteria (five beneficial criteria and six non-beneficial criteria) and seven qualitative criteria (all of them beneficial criteria) for this study. Criteria and objectives of excavator models are given in Table 2. If there are different units in different multiple objectives, this makes optimisation difficult (Brauers, Ginevičius 2013). In this study, qualitative criteria were measured via a survey study using a five point Likert scale $(1=$ "not at all" and $5=$ "to a great extent") except for the "brand experience" criteria. We measured brand experience by conducting a survey, as well as asking decision makers to use a scale between 1 and 3 with respect to their experiences $(1=$ "negative", $2=$ "no idea" and $3=$ "positive"):

- Motor power $\left(X_{1}\right)$ : There are different excavator models with respect to their motor power. Motor power is an important criterion in terms of the usage area of the excavator and the aim of its usage. Motor power ranges from $93 \mathrm{hp}$ to $464 \mathrm{hp}$.

- Bucket size $\left(X_{2}\right)$ : Bucket size is one of the criteria that show excavator capacity. There are different excavator models with respect to bucket size which range from $0.19 \mathrm{~m}^{3}$ to $6.6 \mathrm{~m}^{3}$. 


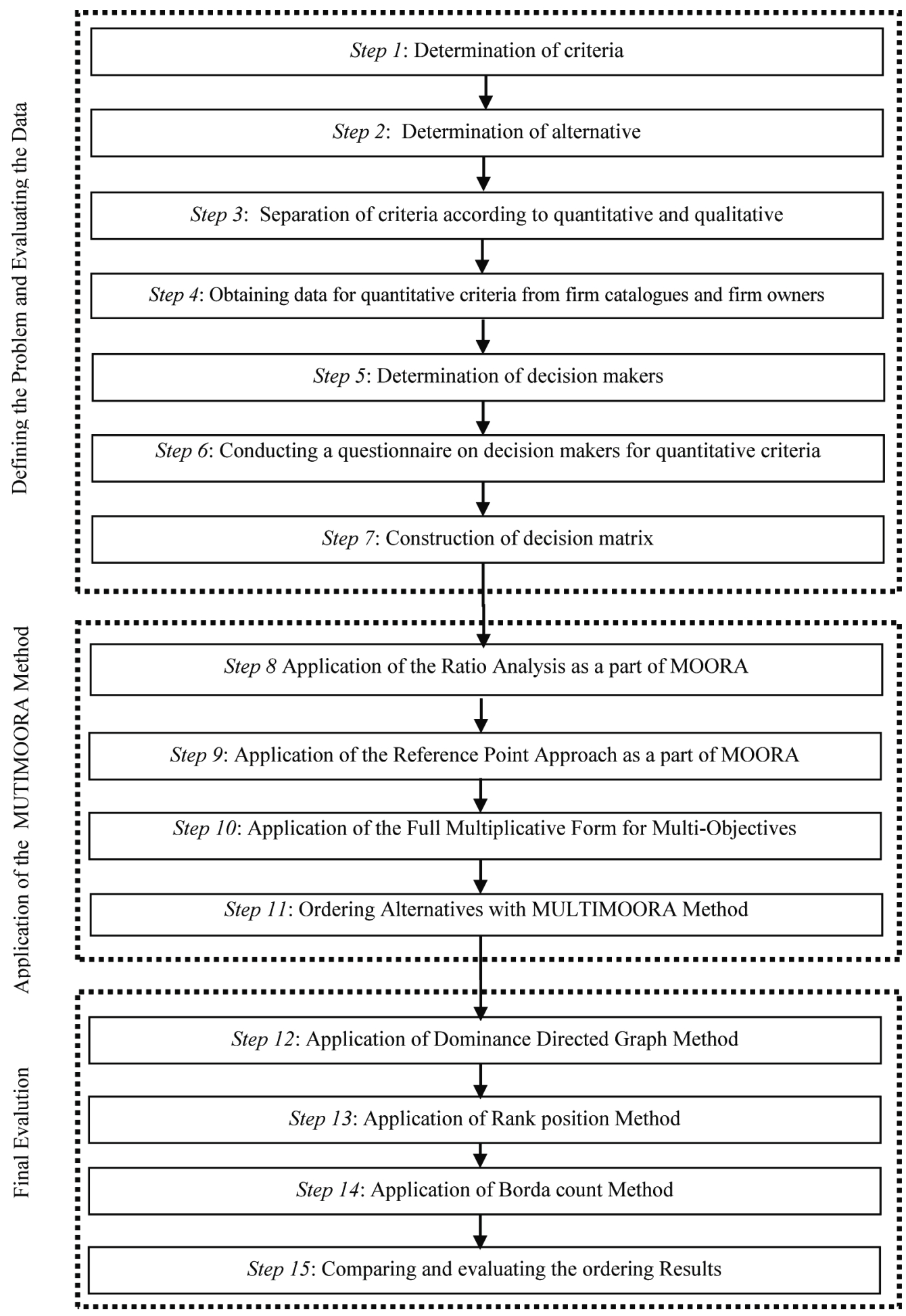

Fig. 2. Application steps 
Table 2. Criteria and objectives of excavator technologies

\begin{tabular}{l|c|c}
\hline \multicolumn{1}{c|}{ Attributes } & Units of measurement & $\max / \min$ \\
\hline Motor power $\left(X_{1}\right)$ & horse power & $\max$ \\
\hline Bucket size $\left(X_{2}\right)$ & $\mathrm{m}^{3}$ & $\max$ \\
\hline Language of product catalogue $\left(X_{3}\right)$ & Turkish / English & $\max$ \\
\hline Lead time $\left(X_{4}\right)$ & days & $\min$ \\
\hline Cutting Height $\left(X_{5}\right)$ & $\mathrm{mm}$ & $\max$ \\
\hline Digging Depth $\left(X_{6}\right)$ & $\mathrm{mm}$ & $\max$ \\
\hline References $\left(X_{7}\right)^{*}$ & - & $\max$ \\
\hline Country of origin $\left(X_{8}\right)^{*}$ & - & $\max$ \\
\hline Product reliability $\left(X_{9}\right)^{*}$ & - & $\max$ \\
\hline Company reputation $\left(X_{10}\right)^{*}$ & - & $\max$ \\
\hline Easiness of selling in the second-hand market $\left(X_{11}\right)^{*}$ & - & $\max$ \\
\hline Brand confidence $\left(X_{12}\right)^{*}$ & - & $\max$ \\
\hline Brand experience $\left(X_{13}\right)^{*}$ & Dollar & $\max$ \\
\hline Purchasing price $\left(X_{14}\right)$ & liter/hour & $\min$ \\
\hline Hydraulic oil consumption $\left(X_{15}\right)$ & liter/hour & $\min$ \\
\hline Engine oil consumption $\left(X_{16}\right)$ & dba & $\min$ \\
\hline Cab comfort $\left(X_{17}\right)$ & liter/hour & $\min$ \\
\hline Fuel consumption $\left(X_{18}\right)$ & - &
\end{tabular}

Note: ${ }^{*}$ The attribute is measured by scale between 1 and 5 via survey study.

- Language of product catalogue $\left(X_{3}\right)$ : Soykan (2009) emphasises that the decision makers prefer the language of the product catalogue for excavators to be in both Turkish and English. However, parts of the product catalogue may be written in only one language, i.e. Turkish or English. We use a three-point scale (1 - English language, 2 - Turkish language, 3 - both English and Turkish language).

- Lead time $\left(X_{4}\right)$ : Decision makers expect a short lead time. If the lead time is high for one excavator model, this negatively affects the company. Delivery speed and timely deliveries affect the decision as to which excavator to purchase.

- Cutting Height $\left(X_{5}\right)$ : Decision makers want to buy an excavator that has a high cutting height due to the fact that this provides high work capacity. It enables the performance of high jobs with less movement, especially in road works.

- Digging Depth $\left(X_{6}\right)$ : Digging depth is quite important when the excavator works on infrastructure. Therefore, decision makers prefer an excavator with greater digging depth.

- References $\left(X_{7}\right)$ : References are indicative of the supplier's relationships with its existing customers that can be used to evaluate the supplier's product or service, management and cooperation performance (Salminen 2001). Customer references can also be considered important marketing tools for companies (Jalkala, Salminen 2009). Ruokolainen and Igel (2004) indicate that the references can be more im- portant than price, delivery capability, or new technological features.

- Country of origin $\left(X_{8}\right)$ : Negative perceptions of the product's country of origin can affect buyers' perceptions towards that product (Samiee 1994). For example, Güdüm and Kavas (1996) researched the Turkish industrial purchasing managers' perceptions of foreign and national industrial suppliers. The results of their study indicate that the managers in Turkey prefer German and Japanese suppliers to US and national suppliers. Therefore, decision makers' perceptions related to country of origin affect the buying decision. Details on the studies related to country of origin criteria can be found in review studies (Al-Sulaiti, Baker 1998; Dinnie 2004).

- Product reliability $\left(X_{9}\right)$ : Product reliability attracts increasing attention from manufacturers as this is a vital factor in a competitive world (Jiang et al. 2010). Murthy et al. (2008) give the following definition: "product reliability conveys the concept of dependability, successful operation of performance and the absence of failures". Homburg and Rudolph (2001) emphasise that product reliability is one of the satisfaction criteria related to product dimension.

- Company reputation $\left(X_{10}\right)$ : Reputation addresses the image of the company to all its constituents, including investors (Mudambi 2002). The company's reputation has a strong influence on buying decisions in many business markets (Cretu, Brodie 2007). A buyer's expectation is also affected by a company's 
reputation and its service offering information (Yoon et al. 1993).

- Easiness of selling in the second-hand market $\left(X_{11}\right)$ : Second-hand products have previously been used by an end user or consumer (Mehrabad et al. 2010). Decision makers prefer excavators that are easier to re-sell in the second-hand market. Baykasoğlu et al. (2012) also addressed the truck selection problem by considering the "easiness of selling in the secondhand market" criteria.

- Brand confidence $\left(X_{12}\right)$ : There are many brands of excavator. During the purchasing process, the buyer considers the brand confidence to decrease the possibility of defects related to the product in the future.

- Brand experience $\left(X_{13}\right)$ : Brand experience is a new consumer psychology concept (Brakus et al. 2012). Brakus et al. (2009) defined brand experiences as "subjective, internal consumer responses (sensations, feelings and cognitions) as well as behavioral responses evoked by brand-related stimuli that are part of a brand's design and identity, packaging, communications and environments".

- Purchasing price $\left(X_{14}\right)$ : One of the key factors affecting the purchasing decision is total price. Stock (2005) defined purchasing price as the actual price paid by a customer, including all of the costs. Decision makers want to buy the cheapest excavator that meets their requirements.

- Hydraulic oil consumption $\left(X_{15}\right)$ : Many thousands of litres of hydraulic oil are consumed for the operation of an excavator. The hydraulic oil pan must be refilled when it becomes empty, which is costly. Therefore, decision makers want to buy an excavator that consumes the least amount of hydraulic oil per hour.

- Engine oil consumption $\left(X_{16}\right)$ : Engine oils reduce wear by reducing friction between moving parts. Engine oil consumption for an excavator may be high depending upon the amount of usage. Therefore, decision makers want to select an excavator that consumes the least amount of engine oil per hour during its operation.

- Cab comfort $\left(X_{17}\right)$ : Cab comfort affects operator fatigue and efficiency directly. The excavator cab should have sound absorption properties, a wide viewing angle, air conditioning and an ergonomic design. These factors influence decision makers and the decision to buy.

- Fuel consumption $\left(X_{18}\right)$ : Fuel for vehicles can be considered one of the most important criteria currently. Decision makers prefer to buy an excavator which consumes less fuel, especially due to the higher cost of fuel in Turkey.

As can be seen from Table 1, there are 12 criteria that should be maximised while the others are minimised. These 12 criteria are called as beneficial criteria. This means that the outcome of these criteria is desired to be as high as possible by decision makers to increase the work capacity and efficiency of an excavator. For example, the language of the product catalogue $\left(X_{3}\right)$ is preferred to be both in Turkish and English by decision makers. A three-point scale (1 - English language, 2 - Turkish language, 3 - both English and Turkish language) is used to measure this criterion and high outcome for an excavator alternative indicates that this meets the standard of the decision maker with respect to $X_{3}$ criterion. In addition, the value of References $\left(X_{7}\right)$ and Country of origin $\left(X_{8}\right)$ are beneficial criteria and they are measured by a scale in between 1 and 5 via survey study. Similar to $X_{3}$ criterion, the outcome of $X_{7}$ and $X_{8}$ criteria are desired to be as high as possible due to these being beneficial criteria. If a decision-maker marked " 5 " for an excavator alternative in the survey study for $X_{7}$ criterion, this means that customers have a good perception in the market for the excavator alternative and it meets the standard of the decision - maker with respect to $X_{3}$ criterion. Similarly, a decision-maker can mark "1" or "2" for an excavator alternative in the survey study for $X_{8}$ criterion if he/she has negative perceptions of the product's country of origin. Decision-makers want to buy an excavator that has high values for beneficial criteria and less value for nonbeneficial criteria.

\subsection{Results}

Table 3 presents the matrix of responses of alternatives on objectives. Based on this matrix as an input, the ranking of the 13 excavator technologies according to the two parts of MOORA, namely, the ratio analysis and the reference point approach, and the full multiplicative form are performed. Details on the calculation of the two parts of MOORA can be found in Tables 7-10 in Appendix A. In addition, Table 11, which is presented in Appendix B, includes the calculation of the full multiplicative form for multi-objectives. Furthermore, Appendix C, which is composed of Tables $12-14$, gives the details of the dominance directed graph calculation. Table 4 shows the ranking by the dominance directed graph based the MULTIMOORA method. Table 5 presents ranking by rank position based the MULTIMOORA method and Borda count method based on the MULTIMOORA method, and Table 6 gives the original MULTIMOORA result for excavator technologies. As can be seen in Tables 4, 5 and 6 , the ranking of excavators according to the original MULTIMOORA and data fusion methods based MULTIMOORA methods have the same ranking $(\mathrm{P}-$ preferred to): E3 -P- E8 -P- E11 -P- E9 -P- E2 -P- E1 -P- E13 -P- E10 -P- E12 -P- E5 -P- E7 -P- E4 -P- E6. The results from this study show that there is no difference between the data fusion methods and the MULTIMORA method can be applied to an excavator selection problem successfully. Excavator 3 (E3) can be recommended to the firm since it ranked first in all results. 
Table 3. Matrix of responses of alternatives on objectives: $\left(x_{i j}\right)$

\begin{tabular}{|c|c|c|c|c|c|c|c|c|c|c|c|c|c|c|c|c|c|c|}
\hline & $X_{1}$ & $\mathbf{X}_{2}$ & $\mathbf{X}_{3}$ & $X_{4}$ & $\mathbf{X}_{5}$ & $\mathbf{X}_{6}$ & $\mathbf{X}_{7}$ & $X_{8}$ & $X_{9}$ & $X_{10}$ & $X_{11}$ & $X_{12}$ & $X_{13}$ & $X_{14}$ & $X_{15}$ & $X_{16}$ & $\mathbf{X}_{17}$ & $X_{18}$ \\
\hline E1 & 169 & 1.61 & 1 & 6 & 11575 & 6655 & 5 & 5 & 5 & 4.6 & 3.6 & 5 & 2.6 & 224941.86 & 750.00 & 30 & 75 & 18 \\
\hline E2 & 202 & 1.70 & 2 & 1 & 14890 & 14210 & 3 & 2.2 & 3 & 3.8 & 3.8 & 4 & 2 & 184043.34 & 925.00 & 38 & 74 & 18 \\
\hline E3 & 177 & 1.50 & 3 & 1 & 10290 & 7290 & 4.6 & 5 & 4.6 & 5 & 4.6 & 5 & 2.6 & 208582.45 & 700.00 & 27 & 70 & 20 \\
\hline E4 & 227 & 1.85 & 1 & 15 & 1140 & 7790 & 3 & 3.2 & 2.2 & 4 & 4.2 & 4.2 & 2.6 & 181440.00 & 640.00 & 24 & 70 & 21 \\
\hline E5 & 230 & 1.85 & 1 & 15 & 11400 & 8090 & 3 & 3.2 & 2.2 & 4 & 4.2 & 4.2 & 2.6 & 147960.00 & 330.00 & 24 & 70 & 21 \\
\hline E6 & 197 & 1.80 & 1 & 20 & 1069 & 723 & 4.4 & 4.4 & 4 & 4.2 & 2.8 & 4.2 & 3 & 170410.50 & 301.25 & 22 & 74 & 21 \\
\hline E7 & 216 & 1.80 & 1 & 20 & 11261 & 7619 & 4.4 & 4.4 & 4 & 4.2 & 2.8 & 4.2 & 3 & 193586.32 & 181.25 & 38 & 74 & 21 \\
\hline E8 & 188 & 1.60 & 2 & 10 & 10130 & 6940 & 4.4 & 5 & 4.8 & 4.6 & 3.6 & 4.6 & 2.6 & 190331.18 & 330.00 & 23 & 74 & 18 \\
\hline E9 & 179 & 1.40 & 2 & 10 & 10000 & 6920 & 4.4 & 5 & 4.8 & 4.6 & 3.6 & 4.6 & 2.6 & 215708.66 & 337.50 & 23 & 74 & 21 \\
\hline E10 & 180 & 1.80 & 1 & 5 & 10730 & 7600 & 4.4 & 3.4 & 4.8 & 4.2 & 3.2 & 4.2 & 2.6 & 159504.22 & 800.00 & 32 & 73 & 17 \\
\hline E11 & 170 & 1.80 & 1 & 5 & 18207 & 14347 & 4.4 & 3.4 & 4.8 & 4.2 & 3.2 & 4.2 & 2.6 & 179953.48 & 320.00 & 30 & 71 & 22 \\
\hline E12 & 192 & 2.10 & 1 & 5 & 11650 & 7580 & 4.4 & 3.4 & 4.8 & 4.2 & 3.2 & 4.2 & 2.6 & 170410.50 & 1000.00 & 32 & 73 & 17 \\
\hline E13 & 195 & 1.40 & 1 & 5 & 10700 & 7300 & 4.4 & 3.4 & 4.8 & 4.2 & 3.2 & 4.2 & 2.6 & 197676.18 & 400 & 30 & 71 & 22 \\
\hline
\end{tabular}

Table 4. Ranking by Dominance directed graph

\begin{tabular}{c|c|c|c|c|c}
\hline & Ratio analysis & Reference point approach & Full multiplicative form & Sum & Rank \\
\hline E1 & 36 & 36 & 28 & 100 & $\mathbf{6}$ \\
\hline E2 & 28 & 45 & 45 & 118 & $\mathbf{5}$ \\
\hline E3 & 80 & 66 & 78 & 224 & $\mathbf{1}$ \\
\hline E4 & 0 & 3 & 1 & 4 & $\mathbf{1 2}$ \\
\hline E5 & 6 & 10 & 3 & 19 & $\mathbf{1 0}$ \\
\hline E6 & 1 & 1 & 0 & 2 & $\mathbf{1 3}$ \\
\hline E7 & 3 & 0 & 6 & 9 & $\mathbf{1 1}$ \\
\hline E8 & 68 & 78 & 55 & 201 & $\mathbf{2}$ \\
\hline E9 & 56 & 55 & 36 & 147 & $\mathbf{4}$ \\
\hline E10 & 15 & 15 & 10 & 40 & $\mathbf{8}$ \\
\hline E11 & 68 & 28 & 66 & 162 & $\mathbf{3}$ \\
\hline E12 & 10 & 6 & 15 & 31 & $\mathbf{9}$ \\
\hline E13 & 21 & 21 & 21 & 63 & $\mathbf{7}$ \\
\hline
\end{tabular}

Table 5. Ranking by Rank position and Borda count methods

\begin{tabular}{c|c|c|c|c}
\hline & \multicolumn{2}{|c|}{ Rank position method } & \multicolumn{2}{c}{ Borda count method } \\
\hline & $\mathrm{r}\left(\mathrm{d}_{\mathrm{i}}\right)$ & Rank $(\mathrm{i})$ & Rank \\
\hline E1 & 1.76 & $\mathbf{6}$ & 26 & $\mathbf{6}$ \\
\hline E2 & 1.50 & $\mathbf{5}$ & 28 & $\mathbf{5}$ \\
\hline E3 & 0.40 & $\mathbf{1}$ & 38 & $\mathbf{1 2}$ \\
\hline E4 & 3.98 & $\mathbf{1 2}$ & 6 & $\mathbf{1 0}$ \\
\hline E5 & 3.31 & $\mathbf{1 0}$ & 12 & $\mathbf{1 3}$ \\
\hline E6 & 4.11 & $\mathbf{1 3}$ & 5 & $\mathbf{1 1}$ \\
\hline E7 & 3.73 & $\mathbf{1 1}$ & 8 & $\mathbf{2}$ \\
\hline E8 & 0.60 & $\mathbf{2}$ & 35 & $\mathbf{4}$ \\
\hline E9 & 1.28 & $\mathbf{4}$ & 30 & $\mathbf{3}$ \\
\hline E10 & 2.77 & $\mathbf{8}$ & 17 & $\mathbf{9}$ \\
\hline E11 & 0.86 & $\mathbf{3}$ & 32 & $\mathbf{7}$ \\
\hline E12 & 2.98 & $\mathbf{9}$ & 15 & 21 \\
\hline E13 & 2.33 & $\mathbf{7}$ & & \\
\hline & & & & 15 \\
\hline
\end{tabular}


Table 6. The original MULTIMOORA results for excavator models

\begin{tabular}{c|c|c|c|c}
\hline & Ratio analysis & Reference point approach & Full multiplicative form & MULTIMOORA \\
\hline E1 & 5 & 5 & 6 & $\mathbf{6}$ \\
\hline E2 & 6 & 4 & 4 & $\mathbf{5}$ \\
\hline E3 & 1 & 2 & 1 & $\mathbf{1}$ \\
\hline E4 & 13 & 11 & 12 & $\mathbf{1 2}$ \\
\hline E5 & 10 & 9 & 11 & $\mathbf{1 0}$ \\
\hline E6 & 12 & 12 & 13 & $\mathbf{1 1}$ \\
\hline E7 & 11 & 13 & 10 & $\mathbf{2}$ \\
\hline E8 & 3 & 1 & 3 & $\mathbf{4}$ \\
\hline E9 & 4 & 3 & 5 & $\mathbf{8}$ \\
\hline E10 & 8 & 8 & 9 & $\mathbf{3}$ \\
\hline E11 & 2 & 6 & 2 & $\mathbf{7}$ \\
\hline E12 & 9 & 10 & 8 & 7 \\
\hline E13 & 7 & 7 & & \\
\hline
\end{tabular}

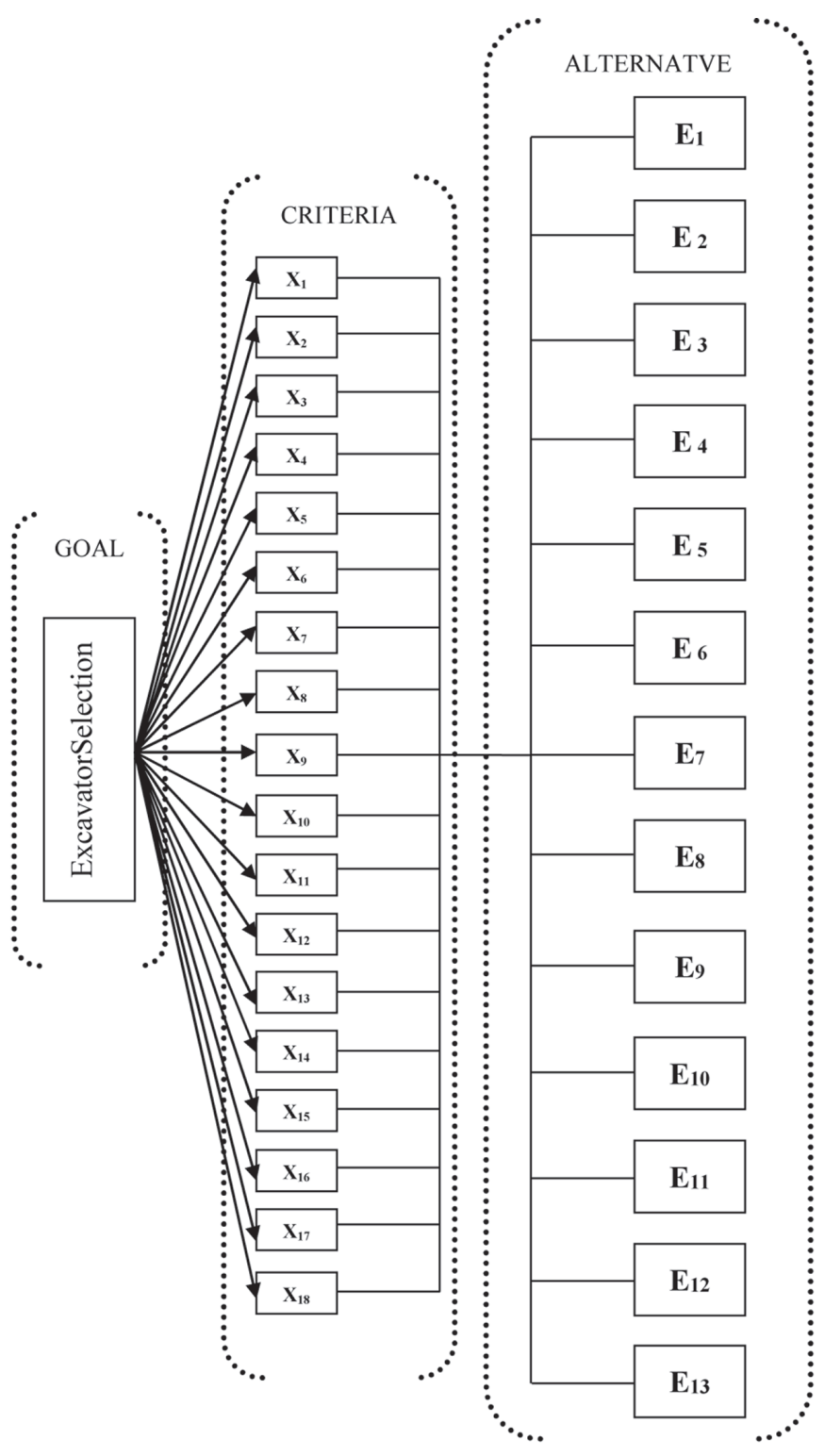

Fig. 3. Hierarchy for excavator technologies evaluation 


\section{Conclusions}

Excavators are very important vehicles for business and construction machinery. The selection of the right excavator technology with respect to considered criteria for a firm provides many benefits, such as maximum efficiency, effectiveness and long economic life. Thirteen excavator technologies, which met the requirements of the decision makers, were ranked in this study according to 18 criteria by using the MULTIMOORA method. These included qualitative, quantitative, beneficial and non-beneficial criteria. There are three reasons for the selection of the MULTIMOORA method. First, its robustness is emphasised in the literature. Second, it considers qualitative, quantitative, beneficial and non-beneficial criteria at the same time. Third, it provides the decision makers with a means to assess the technologies through multiple perspectives.

The MULTIMOORA method uses the theory of dominance to combine the result of the ratio analysis as part of MOORA, Reference Point Theory (the reference point approach as part of MOORA) and the Full Multiplicative Form. In this study, the dominance directed graph, the rank position method and the Borda count method as data fusion methods are also used to combine these three results instead of the theory of dominance. The results show that there is no difference between the data fusion adjusted MULTIMOORA methods and the original MULTIMOORA method. In this study, the MULTIMOORA with the dominance theory is not beaten by other data fusion methods, namely dominance directed graph, rank position method and Borda count method for the evaluation of excavator technologies.

It should be noted that there may be equivalence for some alternatives based on the results of the broad count method. For example, there is equivalence for " $t$ " and " $y$ " if we consider these two ranking list, namely $(x, y, z, t)$ and $(t, x, y, z)$. There are many different criteria for the excavator selection. Most commonly used criteria, which are defined by both reviewing the related literature and marketing managers who work in excavator firms in this paper, are taken into account in the technology evaluation process. More technical criteria such as "breakout force" and "crowd force" can also be considered for evaluation of excavator technology.

For future research, sensitivity analyses can be conducted to examine the best alternative with respect to different criteria values for each alternative technology. In addition, application of the other data fusion methods, such as concordant method and logistic regression, can be conducted. Finally, the importance of the criteria can be taken into account in the evaluation process.

\section{Acknowledgements}

The authors would like to thank the two anonymous reviewers for their insightful comments and suggestions that have significantly improved the paper.

\section{References}

Al-Sulaiti, K. I.; Baker, M. J. 1998. Country of origin effects: a literature review, Marketing Intelligence \& Planning 16(3): 150-199. http://dx.doi.org/10.1108/02634509810217309

Aykul, H.; Yalçın, E.; Ediz, I. G.; Dixon-Hardy, D. W.; Akcakoca, H. 2007. Equipment selection for high selective excavation surface coal mining, The Journal of The Southern African Institute of Mining and Metallurgy 107: 195-210.

Baležentis, T.; Baležentis, A. 2011a. A multi-criteria assessment of relative farming efficiency in the European Union Member States, Žemes Ūkio Mokslai 18(3): 125-135.

Baležentis, A.; Baležentis, T. 2011b. Assessing the efficiency of Lithuanian transport sector by applying the methods of Multimoora and data envelopment analysis, Transport 26(3): 263-270. http://dx.doi.org/10.3846/16484142.2011.621146

Baležentis, T.; Baležentis, A. 2014. A survey on development and applications of the multi-criteria decision making method MULTIMOORA, Journal of Multi-Criteria Decision Analysis 21(3-4): 209-222. http://dx.doi.org/10.1002/mcda.1501

Baležentis, A.; Baležentis, T.; Valkauskas, R. 2010. Evaluating situation of Lithuania in the European Union: Structural indicators and MULTIMOORA method, Technological and Economic Development of Economy 16(4): 578-602. http://dx.doi.org/10.3846/tede.2010.36

Bayazit, O.; Karpak, B.; Yagci, A. 2006. A purchasing decision: Selecting a supplier for a construction company, Journal of Systems Science and Systems Engineering 15(2): 217 231. http://dx.doi.org/10.1007/s11518-006-5009-3

Baykasoğlu, A.; Kaplanoğlu, V.; Durmuşoğlu, Z.; Şahin, C. 2012. Integrating fuzzy DEMATEL and fuzzy hierarchical TOPSIS methods for truck selection, Expert Systems with Applications 40(3): 899-907.

http://dx.doi.org/10.1016/j.eswa.2012.05.046

Bozkurt, I. N.; Gurkok, H.; Ayaz, E. S. 2007. Data fusion and bias. Technical report, Bilkent University. 33 p.

Brakus, J. J.; Schmitt, B.; Lia, Z. 2009. Brand experience: what is it? How is it measured? Does it affect loyalty?, Journal of Marketing 73(3): 52-68. http://dx.doi.org/10.1509/jmkg.73.3.52

Brakus, J. J.; Schmitt, B.; Zarantonello, L. 2012. Brand experience: managerial application of a new consumer psychology concept, in S. S. Posavac (Ed.). Cracking the code leveraging consumer psychology to drive profitability. New York, USA: ME Sharpe, 159-180.

Brauers, W. K. M. 2012. Project management for a country with multiple objectives, Czech Ecenomic Rewiew 6(1): 80-101.

Brauers, W. K. M.; Ginevicius, R. 2009. Robustness in regional development studies. The case of Lithuania, Journal of Business Economics and Management 10(2): 121-140. http://dx.doi.org/10.3846/1611-1699.2009.10.121-140

Brauers, W. K. M.; Ginevicius, R. 2010. The economy of the Belgian regions tested with multimoora, Journal of Business Economics and Management 11(2): 173-209. http://dx.doi.org/10.3846/jbem.2010.09

Brauers, W. K. M.; Ginevičius, R. 2013. How to invest in Belgian shares by MULTIMOORA optimization, Journal of Business Economics and Management 14(5): 940-956. http://dx.doi.org/10.3846/16111699.2013.837244

Brauers, W. K. M.; Zavadskas, E. K. 2006. The MOORA method and its application to privatization in a transition economy, Control and Cybernetics 35(2): 443-469.

Brauers, W. K. M.; Zavadskas, E. K. 2009. Robustness of the multi-objective Moora method with a test for the facilities sector, Technological and Economic Development of Economy 15(2): 352-375.

http://dx.doi.org/10.3846/1392-8619.2009.15.352-375 
Brauers, W. K. M.; Zavadskas, E. K. 2010. Project management by Multimoora as an instrument for transition economies, Technological and Economic Development of Economy 16(1): 5-24. http://dx.doi.org/10.3846/tede.2010.01

Brauers, W. K. M.; Zavadskas, E. K. 2011a. Robustness in economic development studies: The case of Tanzania, New State of MCDM in the $21^{\text {st }}$ Century, Lecture Notes in Economics and Mathematical Systems 648(3): 199-213. http://dx.doi.org/10.1007/978-3-642-19695-9_17

Brauers, W. K. M.; Zavadskas, E. K. 2011b. Multimoora optimization used to decide on a bank loan to buy property, Technological and Economic Development of Economy 17(1): 174-188. http://dx.doi.org/10.3846/13928619.2011.560632

Brauers, W. K. M.; Zavadskas, E. K. 2012. Robustness of Multimoora: a method for multi-objective optimization, Informatica 23(1): 1-25.

Brauers, W. K. M.; Zavadskas, E. K.; Peldschus, F.; Turskis, Z. 2008a. Multi-Objective decision-making for road design, Transport 23(3): 183-193.

http://dx.doi.org/10.3846/1648-4142.2008.23.183-193

Brauers, W. K. M.; Zavadskas, E. K.; Turskis, Z.; Vilutiene, T. 2008b. Multi-objective contractors' ranking by applying the Moora method, Journal of Business Economics and Management 9(4): 245-255. http://dx.doi.org/10.3846/1611-1699.2008.9.245-255

Brauers, W. K M.; Ginevicius, R.; Podvezko, V. 2010. Regional development in Lithuania considering multiple objectives by the Moora method, Technological and Economic Development of Economy 16(4): 613-640. http://dx.doi.org/10.3846/tede.2010.38

Brauers, W. K. M.; Kracka, M.; Zavadskas, E. K. 2012. Lithuanian case study of masonry buildings from the Soviet period, Journal of Civil Engineering and Management 18(3): 444-456. http://dx.doi.org/10.3846/13923730.2012.700944

Brauers, W. K. M.; Kildienė, S.; Zavadskas, E. K.; Kaklauskas, A. 2013. The construction sector in twenty European countries during the recession 2008-2009-country ranking by MULTIMOORA, International Journal of Strategic Property Management 17(1): 58-78. http://dx.doi.org/10.3846/1648715X.2013.775194

Brauers, W. K. M.; Ginevičius, R.; Podviezko, A. 2014. Development of a methodology of evaluation of financial stability of commercial banks, Panoeconomicus 3: 349-367. http://dx.doi.org/10.2298/PAN1403349B

Cebesoy, T. 1999. Hydraulic excavator selection using improved quality comparison method, Journal of Engineering Sciences 5(1): 1001-1008.

Chakraborty, S. 2011. Applications of the MOORA method for decision making in manufacturing environment, The International Journal of Advanced Manufacturing Technology 54(9-12): 1155-1166. http://dx.doi.org/10.1007/s00170-010-2972-0

Chernatony, L. D.; McDonald, M. 2003. Creating powerful brands. Oxford: Burlington. $496 \mathrm{p}$.

Cretu, A. E.; Brodie, R. J. 2007. The influence of brand image and company reputation where manufacturers market to small firms: a customer value perspective, Industrial Marketing Management 36(2): 230-240. http://dx.doi.org/10.1016/j.indmarman.2005.08.013

Datta, S.; Sahu, N.; Mahapatra, S. 2013. Robot selection based on grey-MULTIMOORA approach, Grey Systems: Theory and application 3(2): 201-232.

Dinnie, K. 2004. Country-of-origin 1965-2004: a literature review, Journal of Customer Behaviour 3(2): 165-213. http://dx.doi.org/10.1362/1475392041829537
Dunya newspaper. 2014 [online], [cited 27 August 2014]. Available from Internet: http://www.dunya.com

Erp, M. V.; Schomaker, L. 2000.Variants of the Borda count method for combining ranked classifier hypotheses, in Proceedings of the Seventh International Workshop on Frontiers in Handwriting Recognition, 11-13 September 2000, Amsterdam, Netherlands, 443-452.

Gadakh, V. S. 2011. Application of MOORA method for parametric optimization of milling process, International Journal of Applied Engineering Research 1(4): 743-758.

Galetakis, M.; Papadopoulos, S.; Vasiliou, A.; Roumpos, C. P.; Michalakopoulos, T. 2015. Development of an expert system for the prediction of the performance of bucket-wheel excavators used for the selective mining of multiple-layered lignite deposits, in Proceedings of the $12^{\text {th }}$ International Symposium Continuous Surface Mining - Aachen 2014, Lecture Notes in Production Engineering. Springer International Publishing, 47-58.

Güdüm, A. G.; Kavas, A. 1996. Turkish industrial purchasing managers' perceptions of foreign and national industrial suppliers, European Journal of Marketing 30(8): 10-21. http://dx.doi.org/10.1108/03090569610130070

Homburg, C.; Rudolph, B. 2011. Customer satisfaction in industrial markets: dimensional and multiple role issues, Journal of Business Research 52(1): 15-33. http://dx.doi.org/10.1016/S0148-2963(99)00101-0

Industry Directorate-General. 2010. Türkiye İşve Inşaat Makina ları Alt Sektörü [online], [cited 12 May 2015]. Available from Internet: http:/www.sanayi.gov.tr/Files/Documents/ is_ve_insaat_mak_sektoru_-16082010142908.pdf (in Tükish).

Jalkala, A.; Salminen, R. T. 2009. Communicating customer references on industrial companies' Web sites, Industrial Marketing Management 38: 825-837.

http://dx.doi.org/10.1016/j.indmarman.2008.04.009

Jiang, P.; Guo, B.; Lim, J. H.; Zuo, M. J. 2010. Group judgment of relationship between product reliability and quality characteristics based on Bayesian theory and expert's experience, Expert Systems with Applications 37(10): 6844-6849. http://dx.doi.org/10.1016/j.eswa.2010.03.040

Kalibatas, D.; Turskis, Z. 2008. Multicriteria evaluation of inner climate by using MOORA method, Information Technology and Control 37(1): 79-83.

Karande, P.; Chakraborty, S. 2012. Application of multi-objective optimization on the basis of ratio analysis (MOORA) method for materials selection, Material and Design (37): 317-324. http://dx.doi.org/10.1016/j.matdes.2012.01.013

Kirmanli, C.; Ercelebi, S. G. 2009. An expert system for hydraulic excavator and truck selection in surface mining, The Journal of the Southern African Institute of Mining and Metallurgy 109: 727-738.

Kracka, M.; Brauers, W. K. M.; Zavadskas, E. K. 2010. Ranking heating losses in a building by applying the MULTIMOORA, Inzinerine Ekonomika - Engineering Economics 21(4): 352-359.

Liu, H. C.; You, J. X.; Lu, C.; Shan, M. M. 2014. Application of interval 2-tuple linguistic MULTIMOORA method for health-care waste treatment technology evaluation and selection, Waste Management 34(11): 2355-2364. http://dx.doi.org/10.1016/j.wasman.2014.07.016

Mehrabad, M. S.; Noorossana, R.; Shafiee, M. 2010. Modeling and analysis of effective ways for improving the reliability of second-hand products sold with warranty, The International Journal of Advanced Manufacturing Technology 46(1-4): 253-265. http://dx.doi.org/10.1007/s00170-009-2084-x

Moreira, C. A. P. 2011. Learning to rank academic experts: MSc thesis. Uiversidade Tecnica de Kisboa. 
Morley, D.; Lu, M.; AbouRizk, S. 2013. Utilizing simulation derived quantitative formulas for accurate excavator hauler fleet selection, in Proceedings of the 2013 Winter Simulation Conference, 8-11 December 2013, Washington, DC, USA, 3018-3029.

http://dx.doi.org/10.1109/WSC.2013.6721669

Mudambi, S. 2002. Branding importance in business-to-business markets: three buyer clusters, Industrial Marketing Management 31(6): 525-533. http://dx.doi.org/10.1016/S0019-8501(02)00184-0

Murthy, D. N.; Rausand, P.; Østerås, T. 2008. Product reliability, specification and performance. Berlin: Springer-Verlag. 284 p.

Nuray, R. 2003. Automatic performance evaluation of information retrieval systems using data fusion: Master thesis. Bilkent University, Turkey.

Nuray, R.; Can, F. 2006. Automatic ranking of information retrieval systems using data fusion, Journal Information Processing and Management 42: 595-614. http://dx.doi.org/10.1016/j.ipm.2005.03.023

Özçelik, G.; Aydoğan, E. K.; Gencer, C. 2014. A hybrid moorafuzzy algorithm for special education and rehabilitation center selection, Journal of Military and Information Science 2(3): 53-62. http://dx.doi.org/10.17858/jmisci.53708

Qunzhang, T.; Qiliang, S.; Jun, Y.; Min, S.; Guotao, W. 2011. Study of monitoring parameters selection based on ahp for hydraulic system of excavator, in The Third International Conference on Measuring Technology and Mechatronics Automation, 6-7 January 2011, Shangshai, China, 401405.

Ruokolainen, J.; Igel, B. 2004.The factors of making the first successful customer reference to leverage the business of start-up software company - multiple case study in Thai software industry, Technovation 24(9): 673-681. http://dx.doi.org/10.1016/S0166-4972(02)00130-X

Ruta, D.; Gabrys, B. 2000. An overview of classifier fusion methods, Computing and Information Systems 7: 1-10.
Sahu, A. K.; Sahu, N. K.; Sahu, A. K. 2014. Appraisal of CNC machine tool by integrated MULTI-MOORA-IVGN circumferences, Grey Systems: Theory and Application 4(1): 104-123.

Salminen, R. T. 2001. Success factors of a reference visit - a single case study, Journal of Business \& Industrial Marketing 16(6): 487-507. http://dx.doi.org/10.1108/08858620110403086

Samiee, S. 1994. Customer evaluation of products in a global market, Journal of International Business Studies 25(3): 579-604. http://dx.doi.org/10.1057/palgrave.jibs.8490213

Soykan, Y. 2009. Conjoint analysis in industrial purchasing decisions and an application, Academic Review, International Referred Social Science Electronic Journal 16: 1-18 (in Turkish).

Stankevičienè, J.; Rosov, S. 2013. Implementation of multiobjective evaluation method in public debt risk management, Entrepreneurial Business and Economics Review 1(4): 7-19. http://dx.doi.org/10.15678/EBER.2013.010402

Stock, M. R. 2005. Can customer satisfaction decrease price sensitivity in business-to-business Markets?, Journal of Business-to-Business Marketing 12(3): 59-87. http://dx.doi.org/10.1300/J033v12n03 03

Streimikiene, D.; Balezentis, T. 2013. Multi-objective ranking of climate change mitigation policies and measures in Lithuania, Renewable and Sustainable Energy Reviews 18: 144-153. http://dx.doi.org/10.1016/j.rser.2012.09.040

Wang, D.; Guan, C.; Pan, S.; Zhang, M.; Lin, X. 2009. Performance analysis of hydraulic excavator powertrain hybridization, Automation in Construction 18(3): 249-257. http://dx.doi.org/10.1016/j.autcon.2008.10.001

Yoon, E.; Guffey, H. J.; Kijewski, V. 1993. The effects of information and company reputation on intentions to buy a business service, Journal of Business Research 27(3): $215-228$. http://dx.doi.org/10.1016/0148-2963(93)90027-M 


\begin{tabular}{|c|c|c|c|c|c|c|c|c|c|c|c|c|c|c|c|c|}
\hline & $\stackrel{\infty}{\varkappa}$ & ঙ্ & $\underset{\sim}{\stackrel{\sim}{\sim}}$ & \& & $\exists$ & F & 寻 & $\bar{F}$ & ঙ্ল & 寻 & $\underset{\sim}{\stackrel{\sim}{े}}$ & $\begin{array}{l}\text { 字 } \\
\stackrel{+}{2}\end{array}$ & $\stackrel{\text { \} }{\sim}} &{\underset{+}{+}} &{\underset{i}{n}} &{\stackrel{\infty}{n}} \\
{\hline} &{\text { 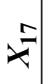 }} &{\text { స్ర }} &{\text { 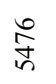 }} &{\text { ஓे }} &{\text { ஓे }} &{\text { ஓे }} &{\begin{array}{l}\text { 号 } \\
\text { 吕 }\end{array}} &{\text { 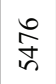 }} &{\begin{array}{l}\text { 号 } \\
\text { 吕 }\end{array}} &{\begin{array}{l}\text { 足 } \\
\text { 点 }\end{array}} &{\text { ते }} &{\text { 离 }} &{\text { ते }} &{\vec{\nabla}} &{\text { 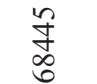 }} &{\begin{array}{l}\text { S. } \\
\dot{0}\end{array}} \\
{\hline} &{\nu^{\infty}} &{\text { §ু }} &{\text { 尃 }} &{\text { ते }} &{\begin{array}{l}\text { 足 } \\
\text { in }\end{array}} &{\text { 号 }} &{\text { 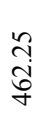 }} &{\text { 导 }} &{\begin{array}{l}\vec{\sigma} \\
\ddot{n} \\
\ddot{n}\end{array}} &{\begin{array}{l}\vec{b} \\
\hat{n} \\
\hat{n}\end{array}} &{\text { さ્ડ }} &{\text { § }} &{\text { さ્ડ }} &{\text { \&ু }} &{\begin{array}{l}\text { fo } \\
\dot{b} \\
\dot{0}\end{array}} &{\text { 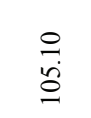 }} \\
{\hline} &{\underset{2}{2}} &{\text { 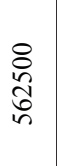 }} &{\begin{array}{l}\text { ते } \\
\text { n్ } \\
\infty\end{array}} &{\begin{array}{l}\text { ڤे } \\
\text { ఫे }\end{array}} &{\text { 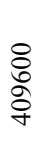 }} &{\begin{array}{l}\stackrel{े}{0} \\
\stackrel{\circ}{=}\end{array}} &{\text { 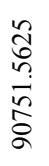 }} &{\text { 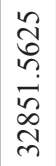 }} &{\text { 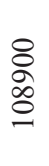 }} &{\text { 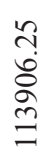 }} &{\text { 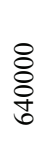 }} &{\begin{array}{l}\stackrel{8}{\grave{d}} \\
\text { d̦ }\end{array}} &{\begin{array}{l}8 \\
\vdots \\
\vdots \\
\vdots\end{array}} &{\begin{array}{l}8 \\
8 \\
\hdashline\end{array}} &{\text { 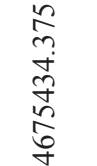 }} &{\text { 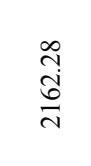 }} \\
{\hline} &{\nu^{ \pm}} &{\text {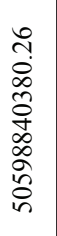 }} &{\text { 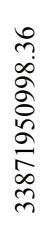 }} &{\text { 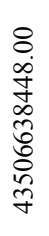 }} &{\text { 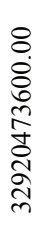 }} &{\begin{array}{l}\stackrel{8}{\circ} \\
\stackrel{\Delta}{0} \\
\stackrel{0}{0} \\
\vec{\sigma} \\
\stackrel{\infty}{\sim}\end{array}} &{\text { 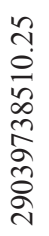 }} &{\text { 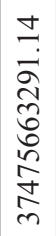 }} &{\text { 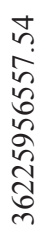 }} &{\text { 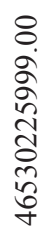 }} &{\text { 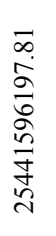 }} &{\text { 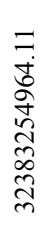 }} &{\text { 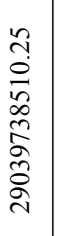 }} &{\text { 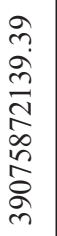 }} &{\text { 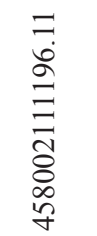 }} &{\begin{array}{l}n \\
n \\
\infty \\
0 \\
\hat{L} \\
\vdots\end{array}} \\
{\hline} &{x^{m}} &{\stackrel{\circ}{\stackrel{0}{6}}} &{\text { 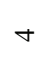 }} &{\stackrel{0}{\stackrel{6}{6}}} &{\stackrel{0}{\circ}} &{\text { ז̊ }} &{a} &{a} &{\text { ז̊ }} &{\frac{\circ}{6}} &{\stackrel{0}{\stackrel{0}{6}}} &{\stackrel{0}{\stackrel{0}{6}}} &{\stackrel{゚}{\stackrel{0}{6}}} &{\frac{\circ}{\stackrel{0}{0}}} &{\begin{array}{l}0 \\
\stackrel{\infty}{\infty}\end{array}} &{\text { fa }} \\
{\hline} &{\approx} &{\approx} &{\text { 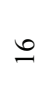 }} &{\approx} &{\begin{array}{l}\text { ț } \\
\text { I }\end{array}} &{\begin{array}{l}\text { ț } \\
\text { I }\end{array}} &{\begin{array}{l}\text { ț } \\
\stackrel{\text {. }}{二}\end{array}} &{\begin{array}{l}\multirow{J}{*}{} \\
\text { I }\end{array}} &{\begin{array}{l}\stackrel{0}{\longrightarrow} \\
\stackrel{\vec{v}}{2}\end{array}} &{\begin{array}{l}\stackrel{0}{-} \\
\stackrel{\vec{\lambda}}{ }\end{array}} &{\text { 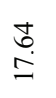 }} &{\text { 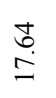 }} &{\text { 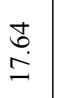 }} &{\begin{array}{l}\text { ț } \\
\stackrel{\text { I }}{ }\end{array}} &{\begin{array}{l}\text { J. } \\
\stackrel{g}{\mathrm{~g}}\end{array}} &{\underset{\hat{\imath}}{\stackrel{a}{a}}} \\
{\hline} &{\neq} &{\stackrel{\text { ¿̊ }}{\text { తి }}} &{\begin{array}{l}\forall \\
\dot{I} \\
\dot{I}\end{array}} &{\stackrel{0}{\stackrel{0}{\vec{v}}}} &{\begin{array}{l}\text { d. } \\
\text { I }\end{array}} &{\text { 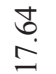 }} &{\underset{\sim}{\stackrel{\infty}{\sim}}} &{\underset{\sim}{\stackrel{\infty}{\sim}}} &{\text { 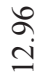 }} &{\text { 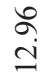 }} &{\stackrel{\stackrel{J}{\Xi}}{\varrho}} &{\text { 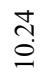 }} &{\text { 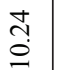 }} &{\stackrel{\stackrel{ }{~}}{\varrho}} &{\text { 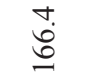 }} &{\text { 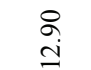 }} \\
{\hline} &{\text { 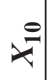 }} &{\stackrel{\circ}{\stackrel{\sim}{\sim}}} &{\begin{array}{l}\underset{J}{J} \\
\stackrel{J}{ \pm}\end{array}} &{\approx} &{\text { 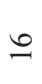 }} &{\mathscr{0}} &{\stackrel{\Xi}{\stackrel{\Xi}{\Xi}}} &{\stackrel{\Xi}{\stackrel{\Xi}{\Xi}}} &{\begin{array}{l}\stackrel{0}{-} \\
\overrightarrow{\vec{v}}\end{array}} &{\begin{array}{l}\stackrel{0}{-} \\
\stackrel{\vec{N}}{N}\end{array}} &{\text { 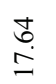 }} &{\begin{array}{l}\stackrel{t}{d} \\
\stackrel{-}{=}\end{array}} &{\stackrel{t}{\stackrel{t}{\leftrightarrows}}} &{\stackrel{\Xi}{\stackrel{\Xi}{\Xi}}} &{\begin{array}{l}\stackrel{0}{2} \\
\stackrel{9}{q}\end{array}} &{\begin{array}{l}n \\
\\
\end{array}} \\
{\hline} &{\text { 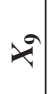 }} &{\ddot{n}} &{a} &{\begin{array}{l}\stackrel{0}{\sim} \\
\vec{\sim}\end{array}} &{\begin{array}{l}\stackrel{\square}{\infty} \\
\stackrel{+}{+}\end{array}} &{\begin{array}{l}\stackrel{+}{\infty} \\
+ \\
+\end{array}} &{\stackrel{0}{0}} &{\stackrel{\circ}{-}} &{\begin{array}{l}\dot{0} \\
\ddot{j}\end{array}} &{\begin{array}{l}\dot{0} \\
\ddot{\sim}\end{array}} &{\begin{array}{l}\vec{\Delta} \\
\stackrel{\sim}{\vec{j}}\end{array}} &{\begin{array}{l}\vec{\Delta} \\
\stackrel{\vec{j}}{\vec{j}}\end{array}} &{\text { 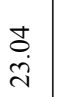 }} &{\text { 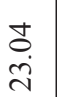 }} &{\text { 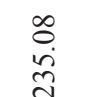 }} &{\stackrel{m}{\stackrel{n}{n}}} \\
{\hline} &{x^{\infty}} &{\text { 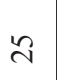 }} &{\text { 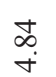 }} &{\approx} &{\text { 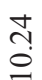 }} &{\text { 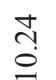 }} &{\begin{array}{l}0 \\
\\
\end{array}} &{\text { 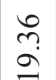 }} &{2} &{\approx} &{\stackrel{\stackrel{0}{n}}{=}} &{\stackrel{\stackrel{\circ}{n}}{=}} &{\text { 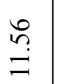 }} &{\text { 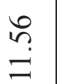 }} &{\text { 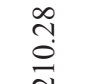 }} &{\begin{array}{l}\stackrel{n}{n} \\
\stackrel{ \pm}{ \pm}\end{array}} \\
{\hline} &{\neq} &{\approx 2} &{a} &{\begin{array}{l}\stackrel{0}{-} \\
\vec{\sim}\end{array}} &{a} &{a} &{\begin{array}{l}0 \\
\stackrel{2}{2} \\
\stackrel{2}{0}\end{array}} &{\begin{array}{l}\stackrel{0}{2} \\
\stackrel{2}{=}\end{array}} &{\text { ֶֻ? }} &{\begin{array}{l}\stackrel{0}{2} \\
\stackrel{2}{2}\end{array}} &{\begin{array}{l}\stackrel{0}{2} \\
2\end{array}} &{\begin{array}{l}\stackrel{0}{2} \\
\stackrel{2}{2}\end{array}} &{\text { ֻூ }} &{\begin{array}{l}\stackrel{0}{2} \\
\stackrel{2}{2}\end{array}} &{\text { 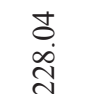 }} &{\stackrel{\circ}{\underline{n}}} \\
{\hline} &{x^{0}} &{\text { 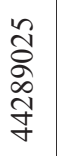 }} &{\text { 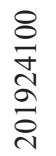 }} &{\frac{8}{\stackrel{8}{\nexists}}} &{\begin{array}{l}8 \\
\frac{1}{+} \\
0 \\
\stackrel{0}{0}\end{array}} &{\text { 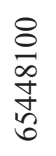 }} &{\text { 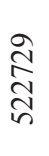 }} &{\begin{array}{l}\overrightarrow{0} \\
\vec{a} \\
\dot{0} \\
\infty \\
i n\end{array}} &{\text { 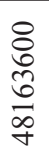 }} &{\begin{array}{l}8 \\
\stackrel{+}{0} \\
\stackrel{0}{0} \\
\infty \\
\stackrel{+}{f}\end{array}} &{\text { 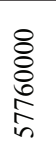 }} &{\text { 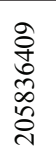 }} &{\text { 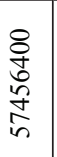 }} &{\begin{array}{l}8 \\
8 \\
8 \\
\grave{~ त े ~} \\
\text { ñ }\end{array}} &{\text { 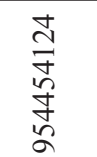 }} &{\text { 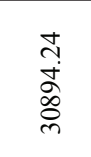 }} \\
{\hline \text { 总 }} &{x^{\circ}} &{\text { 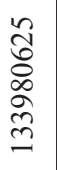 }} &{\text { 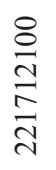 }} &{\begin{array}{l}8 \\
\stackrel{1}{*} \\
\infty \\
\infty \\
\stackrel{\infty}{0}\end{array}} &{\begin{array}{l}8 \\
\text { ¿े } \\
\text { ते }\end{array}} &{\text { 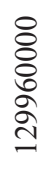 }} &{\begin{array}{l}\vec{D} \\
\stackrel{\vec{J}}{\Xi}\end{array}} &{\begin{array}{l}\vec{\sim} \\
\stackrel{0}{0} \\
\infty \\
0 \\
\stackrel{0}{J}\end{array}} &{\text { 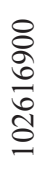 }} &{\begin{array}{l}8 \\
8 \\
8 \\
8 \\
8\end{array}} &{\text { 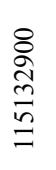 }} &{\text { 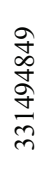 }} &{\begin{array}{l}8 \\
\text { ¿n } \\
\text { त̂ } \\
\text { nn } \\
\end{array}} &{\text { 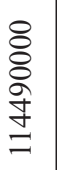 }} &{\text { 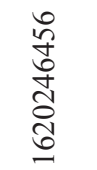 }} &{\begin{array}{l}\text { ते } \\
\text { ते } \\
\text { ơ }\end{array}} \\
{\hline \begin{array}{l}\overrightarrow{\tilde{\omega}} \\
. \overrightarrow{0}\end{array}} &{x^{+}} &{\text {ల్ల }} &{-} &{-} &{\stackrel{\sim}{\sim}} &{\text { ઼ָ }} &{\text { \& }} &{\text { \& }} &{\text { 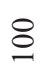 }} &{\text { 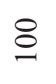 }} &{\text { 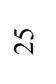 }} &{\stackrel{\sim}{\sim}} &{\text { nิ }} &{\gtrsim} &{\begin{array}{l}\infty \\
\infty \\
i \\
n\end{array}} &{\begin{array}{l}n \\
\infty \\
\dot{m} \\
\dot{m}\end{array}} \\
{\hline \overrightarrow{\widetilde{\sigma}}} &{\approx} &{-} &{\nabla} &{a} &{-} &{-} &{-} &{-} &{\nabla} &{\nabla} &{-} &{-} &{-} &{-} &{\text { in }} &{\begin{array}{l}\stackrel{\infty}{+} \\
i\end{array}} \\
{\hline \text { 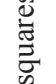 }} &{\text { 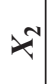 }} &{\text { in }} &{\begin{array}{l}\text { के } \\
\text { i }\end{array}} &{\text { 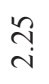 }} &{\stackrel{\text { ㄱ. }}{\text { r }}} &{\stackrel{\text { fै }}{r}} &{\underset{\sim}{\stackrel{\Xi}{n}}} &{\underset{n}{\stackrel{J}{n}}} &{\begin{array}{l}\stackrel{0}{n} \\
\text { r }\end{array}} &{\stackrel{\circ}{-}} &{\underset{n}{\stackrel{J}{n}}} &{\underset{\sim}{\stackrel{J}{n}}} &{\underset{+}{F}} &{\stackrel{\circ}{\Im}} &{\begin{array}{l}\underset{f}{f} \\
\stackrel{\infty}{\infty}\end{array}} &{\text { 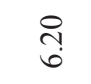 }} \\
{\hline \text { 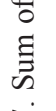 }} &{\mp} &{\begin{array}{l}\overrightarrow{0} \\
\text { o } \\
\text { ì }\end{array}} &{\text { 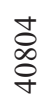 }} &{\frac{\vec{m}}{m}} &{\begin{array}{l}\text { ते } \\
\text { ते }\end{array}} &{\begin{array}{l}8 \\
\text { ते } \\
\text { }\end{array}} &{\text { 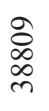 }} &{\text { 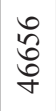 }} &{\text { 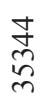 }} &{\text { 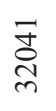 }} &{\text { 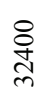 }} &{\begin{array}{l}\stackrel{े}{\grave{\alpha}} \\
\text { ஸे }\end{array}} &{\text { 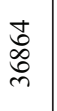 }} &{\text { 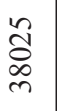 }} &{\begin{array}{l}\underset{b}{\sigma} \\
\underset{g}{g}\end{array}} &{\begin{array}{l}\hat{a} \\
\hat{s}\end{array}} \\
{\hline \frac{0}{d}} &{ } &{\text { 조 }} &{\text { న్ }} &{\text { 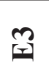 }} &{\text { 亲 }} &{\text { 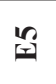 }} &{\text { 도 }} &{\text { 氠 }} &{\text { 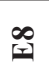 }} &{\text { ब્રે }} &{\text { 오 }} &{\text { 포 }} &{\text { 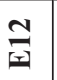 }} &{\frac{9}{2}} &{\begin{array}{l}\text { sərenbs } \\
\text { jo uns }\end{array}} &{\begin{array}{c}\text { s100.I } \\
\text { alenbs }\end{array}} \\
$\hline
\end{tabular}




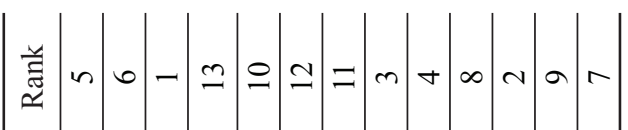

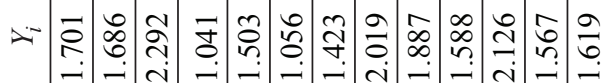

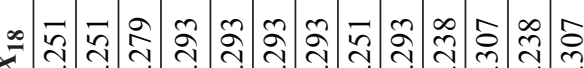

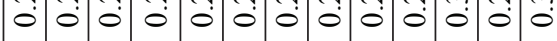

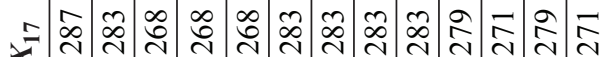

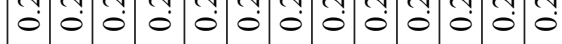

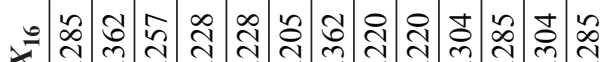

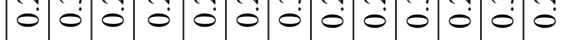

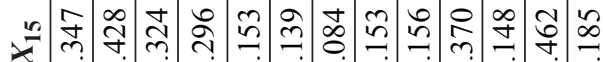

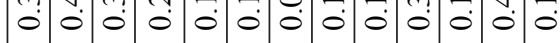

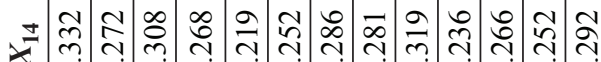

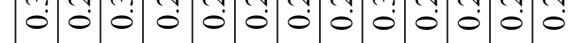

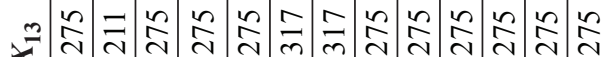

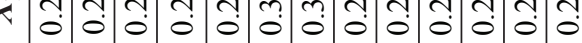

营

$\pi$

ส

$\frac{n}{n}$

สี

윰

荧

อิ

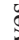

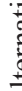

$\frac{\pi}{\pi}$

फ

竞

점

$\bar{z}$

농

ㄴ.

荧

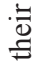

ลे

ఫृ

:

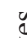

.

$\frac{0}{\frac{0}{0}}$

$\infty$

$\frac{\frac{0}{0}}{\frac{\pi}{-1}}$ $\because \bumpeq$ กิ ปิ

○ே.

$=$ 帘

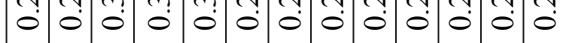

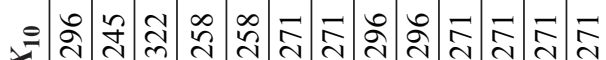

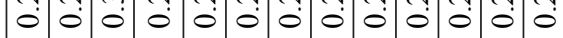

r

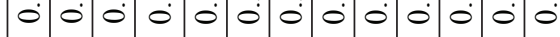

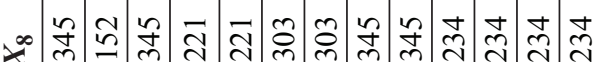
○े

n $\begin{array}{llllllllllllllllllll}0 & 0 & 0 & 0 & 0 & 0 & 0 & 0 & 0 & 0 & 0 & 0 & 0\end{array}$

น

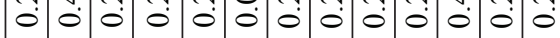

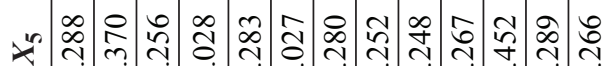
ஸุ.

x

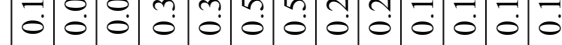

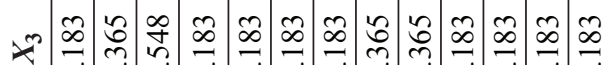
:)

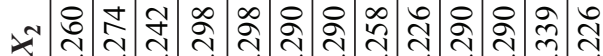

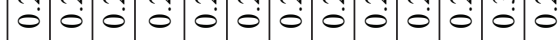

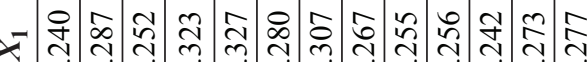

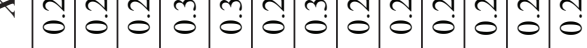

可至望

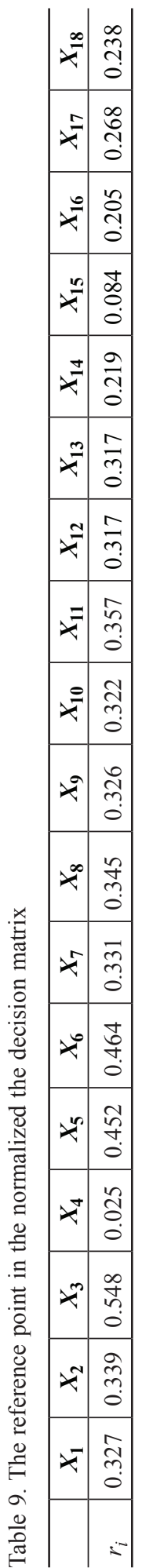

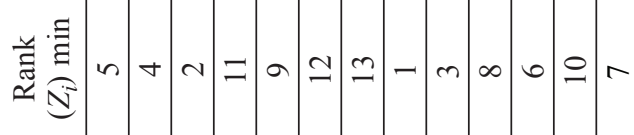

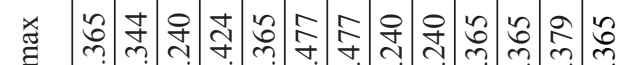

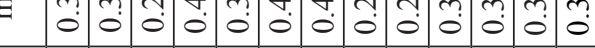

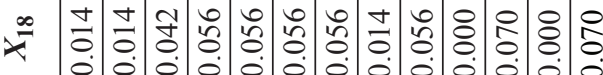

×

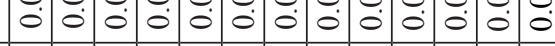

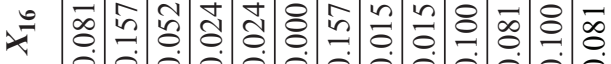

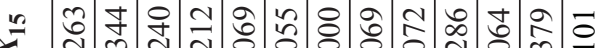

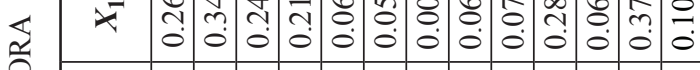

ह

*

0.00 .0

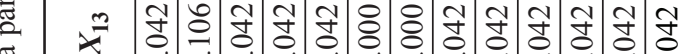

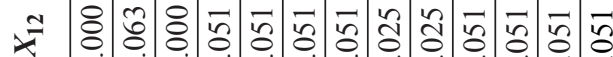

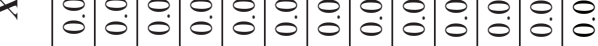

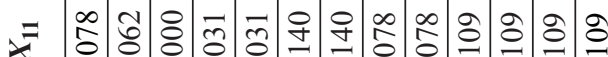

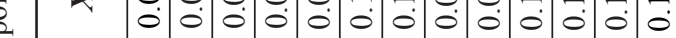

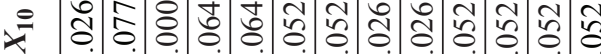

ฉ

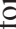

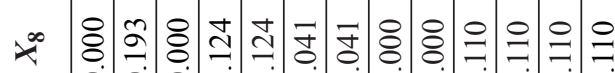

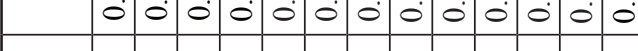

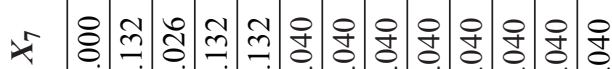
$00: 000: 0.0$

.

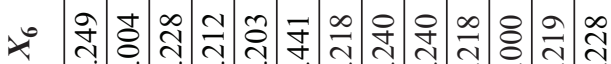
00000000

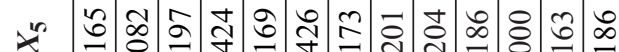
$\div 0.00000$

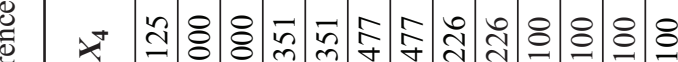

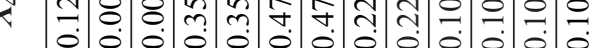

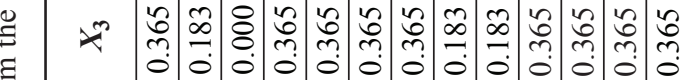
キ

政

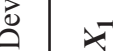

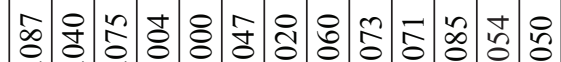
$\div \quad:: 0: 0: 0:: 0:: 0$

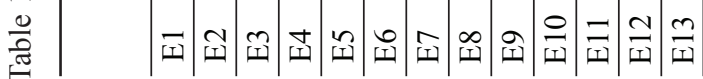




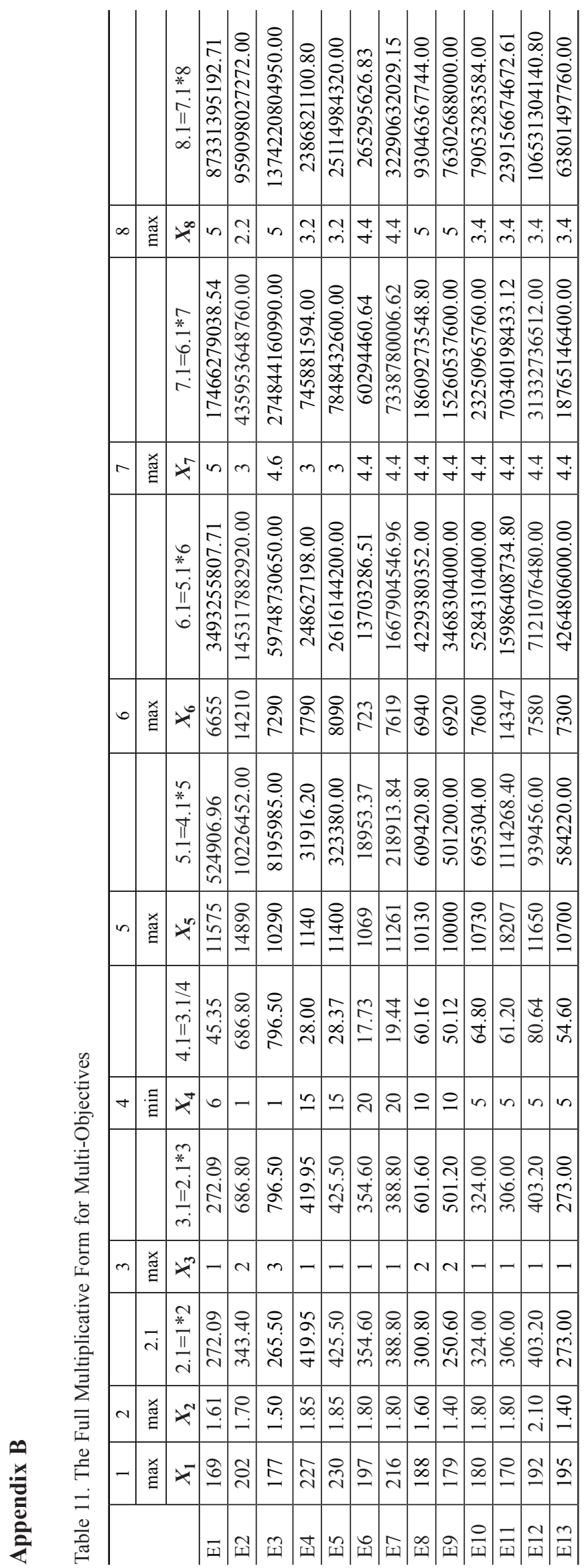




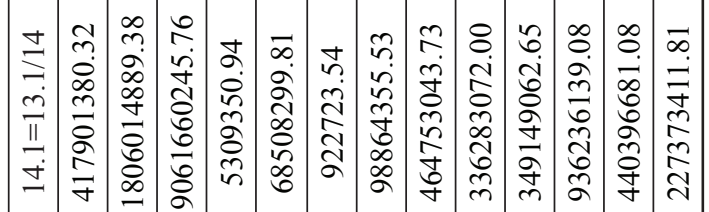

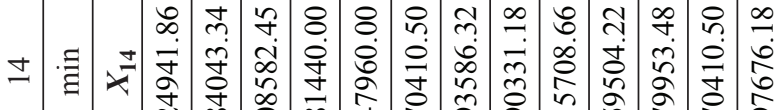
สิ

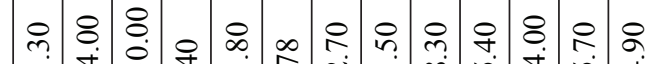

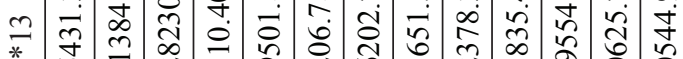

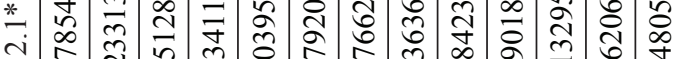

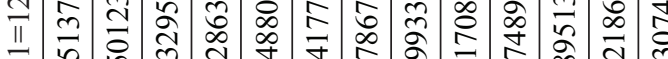

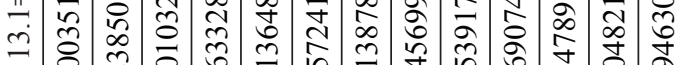

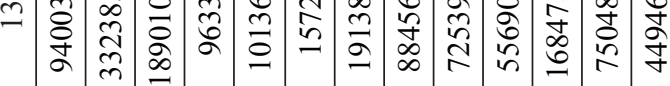

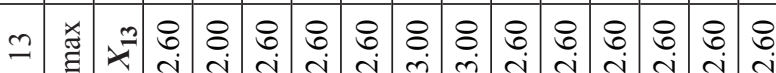

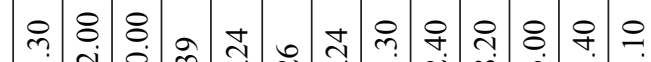

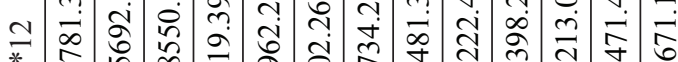
* =11 II

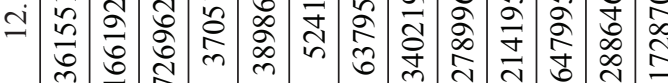

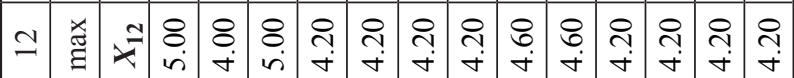

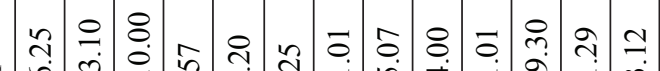

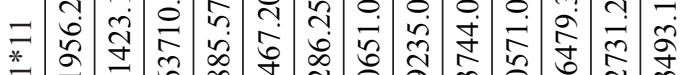

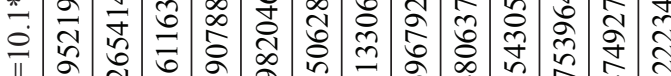

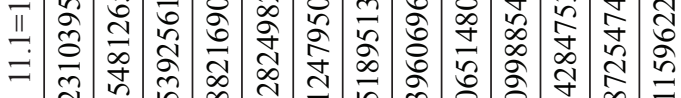

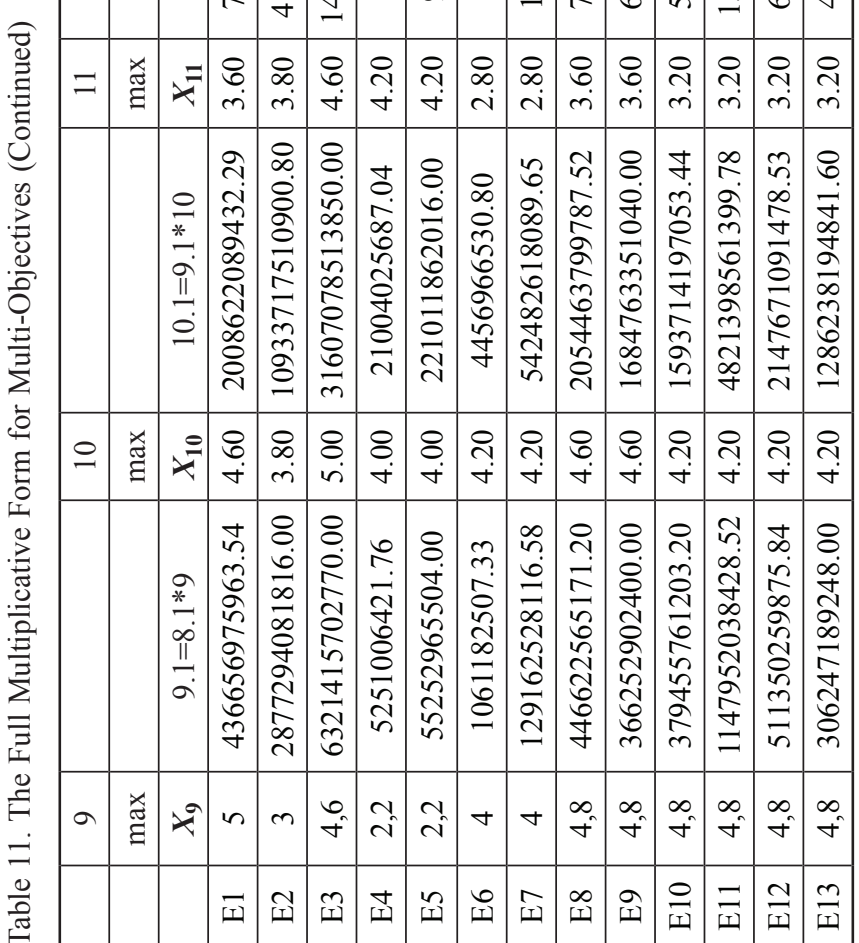

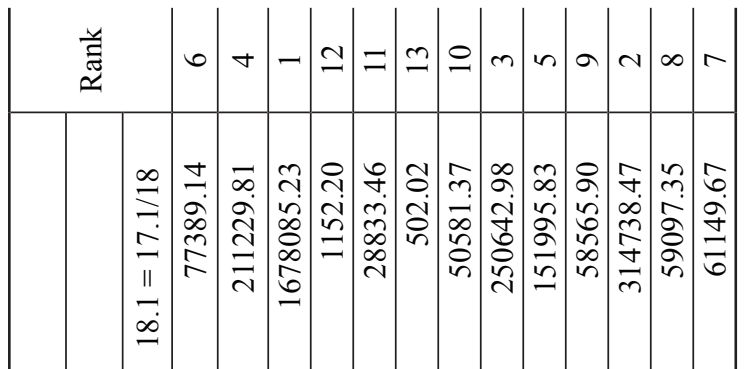

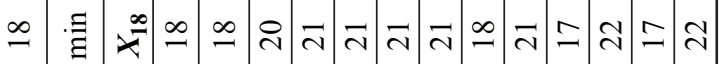

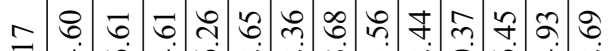

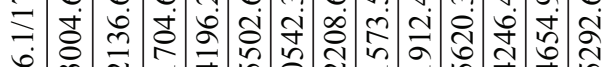

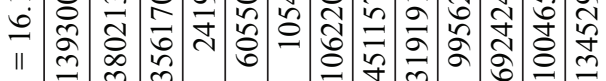
근

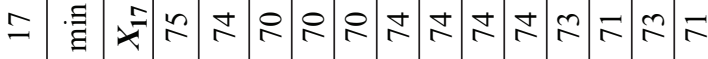

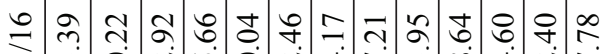

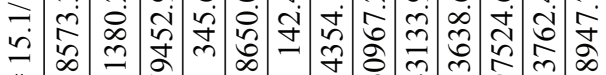

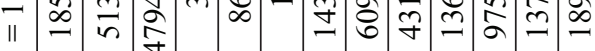
$\underset{6}{-1}$

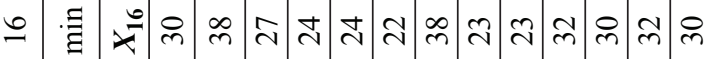

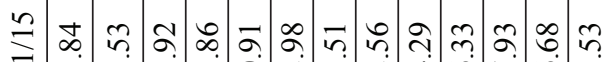

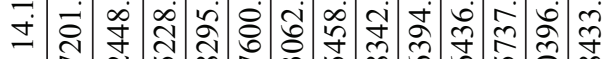

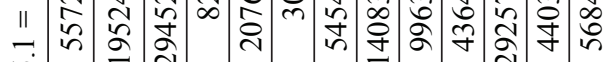
in

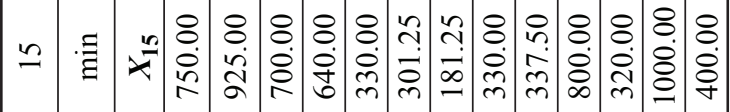

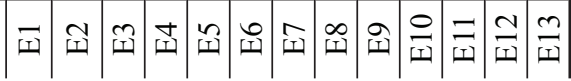


Appendix C

Table 12. The result of Dominance Directed Graph for the ratio analysis as a part of MOORA method

\begin{tabular}{|c|c|c|c|c|c|c|c|c|c|c|c|c|c|}
\hline & \multicolumn{10}{|c|}{ M } \\
\hline & E1 & E2 & E3 & E4 & E5 & E6 & E7 & E8 & E9 & E10 & E11 & E12 & E13 \\
\hline E1 & 0 & 1 & 0 & 1 & 1 & 1 & 1 & 0 & 0 & 1 & 0 & 1 & 1 \\
\hline E2 & 0 & 0 & 0 & 1 & 1 & 1 & 1 & 0 & 0 & 1 & 0 & 1 & 1 \\
\hline E3 & 1 & 1 & 0 & 1 & 1 & 1 & 1 & 1 & 1 & 1 & 1 & 1 & 1 \\
\hline E4 & 0 & 0 & 0 & 0 & 0 & 0 & 0 & 0 & 0 & 0 & 0 & 0 & 0 \\
\hline E5 & 0 & 0 & 0 & 1 & 0 & 1 & 1 & 0 & 0 & 0 & 0 & 0 & 0 \\
\hline E6 & 0 & 0 & 0 & 1 & 0 & 0 & 0 & 0 & 0 & 0 & 0 & 0 & 0 \\
\hline E7 & 0 & 0 & 0 & 1 & 0 & 1 & 0 & 0 & 0 & 0 & 0 & 0 & 0 \\
\hline E8 & 1 & 1 & 0 & 1 & 1 & 1 & 1 & 1 & 1 & 1 & 0 & 1 & 1 \\
\hline E9 & 1 & 1 & 0 & 1 & 1 & 1 & 1 & 0 & 1 & 1 & 0 & 1 & 1 \\
\hline E10 & 0 & 0 & 0 & 1 & 1 & 1 & 1 & 0 & 0 & 0 & 0 & 1 & 0 \\
\hline E11 & 1 & 1 & 0 & 1 & 1 & 1 & 1 & 1 & 1 & 1 & 0 & 1 & 1 \\
\hline E12 & 0 & 0 & 0 & 1 & 1 & 1 & 1 & 0 & 0 & 0 & 0 & 0 & 0 \\
\hline E13 & 0 & 0 & 0 & 1 & 1 & 1 & 1 & 0 & 0 & 1 & 0 & 1 & 0 \\
\hline
\end{tabular}

\begin{tabular}{|c|c|c|c|c|c|c|c|c|c|c|c|c|c|}
\hline \multicolumn{110}{|c|}{ M2 } \\
\hline & E1 & E2 & E3 & E4 & E5 & E6 & E7 & E8 & E9 & E10 & E11 & E12 & E13 \\
\hline E1 & 0 & 0 & 0 & 7 & 4 & 6 & 5 & 0 & 0 & 2 & 0 & 3 & 1 \\
\hline E2 & 0 & 0 & 0 & 6 & 3 & 5 & 4 & 0 & 0 & 1 & 0 & 2 & 0 \\
\hline E3 & 3 & 4 & 0 & 11 & 8 & 10 & 9 & 2 & 3 & 6 & 0 & 7 & 5 \\
\hline E4 & 0 & 0 & 0 & 0 & 0 & 0 & 0 & 0 & 0 & 0 & 0 & 0 & 0 \\
\hline E5 & 0 & 0 & 0 & 2 & 0 & 1 & 0 & 0 & 0 & 0 & 0 & 0 & 0 \\
\hline E6 & 0 & 0 & 0 & 0 & 0 & 0 & 0 & 0 & 0 & 0 & 0 & 0 & 0 \\
\hline E7 & 0 & 0 & 0 & 1 & 0 & 0 & 0 & 0 & 0 & 0 & 0 & 0 & 0 \\
\hline E8 & 2 & 3 & 0 & 10 & 7 & 9 & 8 & 1 & 2 & 5 & 0 & 6 & 4 \\
\hline E9 & 1 & 2 & 0 & 9 & 6 & 8 & 7 & 0 & 1 & 4 & 0 & 5 & 3 \\
\hline E10 & 0 & 0 & 0 & 4 & 1 & 3 & 2 & 0 & 0 & 0 & 0 & 0 & 0 \\
\hline E11 & 2 & 3 & 0 & 10 & 7 & 9 & 8 & 1 & 2 & 5 & 0 & 6 & 4 \\
\hline E12 & 0 & 0 & 0 & 3 & 0 & 2 & 1 & 0 & 0 & 0 & 0 & 0 & 0 \\
\hline E13 & 0 & 0 & 0 & 5 & 2 & 4 & 3 & 0 & 0 & 0 & 0 & 1 & 0 \\
\hline
\end{tabular}

\begin{tabular}{|c|c|c|c|c|c|c|c|c|c|c|c|c|c|c|}
\hline \multicolumn{10}{|c|}{$\mathrm{A}=\mathrm{M}+\mathrm{M} 2$} \\
\hline & E1 & E2 & E3 & E4 & E5 & E6 & E7 & E8 & E9 & E10 & E11 & E12 & E13 & Sum \\
\hline E1 & 0 & 1 & 0 & 8 & 5 & 7 & 6 & 0 & 0 & 3 & 0 & 4 & 2 & 36 \\
E2 & 0 & 0 & 0 & 7 & 4 & 6 & 5 & 0 & 0 & 2 & 0 & 3 & 1 & 28 \\
E3 & 4 & 5 & 0 & 12 & 9 & 11 & 10 & 3 & 4 & 7 & 1 & 8 & 6 & 80 \\
E4 & 0 & 0 & 0 & 0 & 0 & 0 & 0 & 0 & 0 & 0 & 0 & 0 & 0 & 0 \\
E5 & 0 & 0 & 0 & 3 & 0 & 2 & 1 & 0 & 0 & 0 & 0 & 0 & 0 & 6 \\
E6 & 0 & 0 & 0 & 1 & 0 & 0 & 0 & 0 & 0 & 0 & 0 & 0 & 0 & 1 \\
E7 & 0 & 0 & 0 & 2 & 0 & 1 & 0 & 0 & 0 & 0 & 0 & 0 & 0 & 3 \\
E8 & 3 & 4 & 0 & 11 & 8 & 10 & 9 & 2 & 3 & 6 & 0 & 7 & 5 & 68 \\
E9 & 2 & 3 & 0 & 10 & 7 & 9 & 8 & 0 & 2 & 5 & 0 & 6 & 4 & 56 \\
E10 & 0 & 0 & 0 & 5 & 2 & 4 & 3 & 0 & 0 & 0 & 0 & 1 & 0 & 15 \\
E11 & 3 & 4 & 0 & 11 & 8 & 10 & 9 & 2 & 3 & 6 & 0 & 7 & 5 & 68 \\
E12 & 0 & 0 & 0 & 4 & 1 & 3 & 2 & 0 & 0 & 0 & 0 & 0 & 0 & 10 \\
E13 & 0 & 0 & 0 & 6 & 3 & 5 & 4 & 0 & 0 & 1 & 0 & 2 & 0 & 21 \\
\hline
\end{tabular}


Table 13. The result of Dominance Directed Graph for the reference point approach as a part of MOORA method

\begin{tabular}{|c|c|c|c|c|c|c|c|c|c|c|c|c|c|}
\hline \multicolumn{10}{|c|}{ M } \\
\hline & E1 & E2 & E3 & E4 & E5 & E6 & E7 & E8 & E9 & E10 & E11 & E12 & E13 \\
\hline E1 & 0 & 0 & 0 & 1 & 1 & 1 & 1 & 0 & 0 & 1 & 1 & 1 & 1 \\
\hline E2 & 1 & 0 & 0 & 1 & 1 & 1 & 1 & 0 & 0 & 1 & 1 & 1 & 1 \\
\hline E3 & 1 & 1 & 0 & 1 & 1 & 1 & 1 & 0 & 1 & 1 & 1 & 1 & 1 \\
\hline E4 & 0 & 0 & 0 & 0 & 0 & 1 & 1 & 0 & 0 & 0 & 0 & 0 & 0 \\
\hline E5 & 0 & 0 & 0 & 1 & 0 & 1 & 1 & 0 & 0 & 0 & 0 & 1 & 0 \\
\hline E6 & 0 & 0 & 0 & 0 & 0 & 0 & 1 & 0 & 0 & 0 & 0 & 0 & 0 \\
\hline E7 & 0 & 0 & 0 & 0 & 0 & 0 & 0 & 0 & 0 & 0 & 0 & 0 & 0 \\
\hline E8 & 1 & 1 & 1 & 1 & 1 & 1 & 1 & 0 & 1 & 1 & 1 & 1 & 1 \\
\hline E9 & 1 & 1 & 0 & 1 & 1 & 1 & 1 & 0 & 0 & 1 & 1 & 1 & 1 \\
\hline E10 & 0 & 0 & 0 & 1 & 1 & 1 & 1 & 0 & 0 & 0 & 0 & 1 & 0 \\
\hline E11 & 0 & 0 & 0 & 1 & 1 & 1 & 1 & 0 & 0 & 1 & 0 & 1 & 1 \\
\hline E12 & 0 & 0 & 0 & 1 & 0 & 1 & 1 & 0 & 0 & 0 & 0 & 0 & 0 \\
\hline E13 & 0 & 0 & 0 & 1 & 1 & 1 & 1 & 0 & 0 & 1 & 0 & 1 & 0 \\
\hline
\end{tabular}

\begin{tabular}{|c|c|c|c|c|c|c|c|c|c|c|c|c|c|}
\hline \multicolumn{10}{|c|}{ M2 } \\
\hline & E1 & E2 & E3 & E4 & E5 & E6 & E7 & E8 & E9 & E10 & E11 & E12 & E13 \\
\hline E1 & 0 & 0 & 0 & 5 & 3 & 6 & 7 & 0 & 0 & 2 & 0 & 4 & 1 \\
\hline E2 & 0 & 0 & 0 & 6 & 4 & 7 & 8 & 0 & 0 & 3 & 1 & 5 & 2 \\
\hline E3 & 2 & 1 & 0 & 8 & 6 & 9 & 10 & 0 & 0 & 5 & 3 & 7 & 4 \\
\hline E4 & 0 & 0 & 0 & 0 & 0 & 0 & 1 & 0 & 0 & 0 & 0 & 0 & 0 \\
\hline E5 & 0 & 0 & 0 & 1 & 0 & 2 & 3 & 0 & 0 & 0 & 0 & 0 & 0 \\
\hline E6 & 0 & 0 & 0 & 0 & 0 & 0 & 0 & 0 & 0 & 0 & 0 & 0 & 0 \\
\hline E7 & 0 & 0 & 0 & 0 & 0 & 0 & 0 & 0 & 0 & 0 & 0 & 0 & 0 \\
\hline E8 & 3 & 2 & 0 & 9 & 7 & 10 & 11 & 0 & 1 & 6 & 4 & 8 & 5 \\
\hline E9 & 1 & 0 & 0 & 7 & 5 & 8 & 9 & 0 & 0 & 4 & 2 & 6 & 3 \\
\hline E10 & 0 & 0 & 0 & 2 & 0 & 3 & 4 & 0 & 0 & 0 & 0 & 1 & 0 \\
\hline E11 & 0 & 0 & 0 & 4 & 2 & 5 & 6 & 0 & 0 & 1 & 0 & 3 & 0 \\
\hline E12 & 0 & 0 & 0 & 0 & 0 & 1 & 2 & 0 & 0 & 0 & 0 & 0 & 0 \\
\hline E13 & 0 & 0 & 0 & 3 & 1 & 4 & 5 & 0 & 0 & 0 & 0 & 2 & 0 \\
\hline
\end{tabular}

\begin{tabular}{|c|c|c|c|c|c|c|c|c|c|c|c|c|c|c|}
\hline \multicolumn{10}{|c|}{ A $=$ M M2 } \\
\hline & E1 & E2 & E3 & E4 & E5 & E6 & E7 & E8 & E9 & E10 & E11 & E12 & E13 & Sum \\
\hline E1 & 0 & 0 & 0 & 6 & 4 & 7 & 8 & 0 & 0 & 3 & 1 & 5 & 2 & 36 \\
\hline E2 & 1 & 0 & 0 & 7 & 5 & 8 & 9 & 0 & 0 & 4 & 2 & 6 & 3 & 45 \\
\hline E3 & 3 & 2 & 0 & 9 & 7 & 10 & 11 & 0 & 1 & 6 & 4 & 8 & 5 & 66 \\
\hline E4 & 0 & 0 & 0 & 0 & 0 & 1 & 2 & 0 & 0 & 0 & 0 & 0 & 0 & 3 \\
\hline E5 & 0 & 0 & 0 & 2 & 0 & 3 & 4 & 0 & 0 & 0 & 0 & 1 & 0 & 10 \\
\hline E6 & 0 & 0 & 0 & 0 & 0 & 0 & 1 & 0 & 0 & 0 & 0 & 0 & 0 & 1 \\
\hline E7 & 0 & 0 & 0 & 0 & 0 & 0 & 0 & 0 & 0 & 0 & 0 & 0 & 0 & 0 \\
\hline E8 & 4 & 3 & 1 & 10 & 8 & 11 & 12 & 0 & 2 & 7 & 5 & 9 & 6 & 78 \\
\hline E9 & 2 & 1 & 0 & 8 & 6 & 9 & 10 & 0 & 0 & 5 & 3 & 7 & 4 & 55 \\
\hline E10 & 0 & 0 & 0 & 3 & 1 & 4 & 5 & 0 & 0 & 0 & 0 & 2 & 0 & 15 \\
\hline E11 & 0 & 0 & 0 & 5 & 3 & 6 & 7 & 0 & 0 & 2 & 0 & 4 & 1 & 28 \\
\hline E12 & 0 & 0 & 0 & 1 & 0 & 2 & 3 & 0 & 0 & 0 & 0 & 0 & 0 & 6 \\
\hline E13 & 0 & 0 & 0 & 4 & 2 & 5 & 6 & 0 & 0 & 1 & 0 & 3 & 0 & 21 \\
\hline
\end{tabular}


Table 14. The result of Dominance Directed Graph for the full multiplicative form for multi-objective

\begin{tabular}{|c|c|c|c|c|c|c|c|c|c|c|c|c|c|}
\hline \multicolumn{10}{|c|}{ M } \\
\hline & E1 & E2 & E3 & E4 & E5 & E6 & E7 & E8 & E9 & E10 & E11 & E12 & E13 \\
\hline E1 & 0 & 0 & 0 & 1 & 1 & 1 & 1 & 0 & 0 & 1 & 0 & 1 & 1 \\
\hline E2 & 1 & 0 & 0 & 1 & 1 & 1 & 1 & 0 & 1 & 1 & 0 & 1 & 1 \\
\hline E3 & 1 & 1 & 0 & 1 & 1 & 1 & 1 & 1 & 1 & 1 & 1 & 1 & 1 \\
\hline E4 & 0 & 0 & 0 & 0 & 0 & 1 & 0 & 0 & 0 & 0 & 0 & 0 & 0 \\
\hline E5 & 0 & 0 & 0 & 1 & 0 & 1 & 0 & 0 & 0 & 0 & 0 & 0 & 0 \\
\hline E6 & 0 & 0 & 0 & 0 & 0 & 0 & 0 & 0 & 0 & 0 & 0 & 0 & 0 \\
\hline E7 & 0 & 0 & 0 & 1 & 1 & 1 & 0 & 0 & 0 & 0 & 0 & 0 & 0 \\
\hline E8 & 1 & 1 & 0 & 1 & 1 & 1 & 1 & 0 & 1 & 1 & 0 & 1 & 1 \\
\hline E9 & 1 & 0 & 0 & 1 & 1 & 1 & 1 & 0 & 0 & 1 & 0 & 1 & 1 \\
\hline E10 & 0 & 0 & 0 & 1 & 1 & 1 & 1 & 0 & 0 & 0 & 0 & 0 & 0 \\
\hline E11 & 1 & 1 & 0 & 1 & 1 & 1 & 1 & 1 & 1 & 1 & 0 & 1 & 1 \\
\hline E12 & 0 & 0 & 0 & 1 & 1 & 1 & 1 & 0 & 0 & 1 & 0 & 0 & 0 \\
\hline E13 & 0 & 0 & 0 & 1 & 1 & 1 & 1 & 0 & 0 & 1 & 0 & 1 & 0 \\
\hline
\end{tabular}

\begin{tabular}{|c|c|c|c|c|c|c|c|c|c|c|c|c|c|}
\hline \multicolumn{10}{|c|}{ M2 } \\
\hline & E1 & E2 & E3 & E4 & E5 & E6 & E7 & E8 & E9 & E10 & E11 & E12 & E13 \\
\hline E1 & 0 & 0 & 0 & 5 & 4 & 6 & 3 & 0 & 0 & 2 & 0 & 1 & 0 \\
\hline E2 & 1 & 0 & 0 & 7 & 6 & 8 & 5 & 0 & 0 & 4 & 0 & 3 & 2 \\
\hline E3 & 4 & 2 & 0 & 10 & 9 & 11 & 8 & 1 & 3 & 7 & 0 & 6 & 5 \\
\hline E4 & 0 & 0 & 0 & 0 & 0 & 0 & 0 & 0 & 0 & 0 & 0 & 0 & 0 \\
\hline E5 & 0 & 0 & 0 & 0 & 0 & 1 & 0 & 0 & 0 & 0 & 0 & 0 & 0 \\
\hline E6 & 0 & 0 & 0 & 0 & 0 & 0 & 0 & 0 & 0 & 0 & 0 & 0 & 0 \\
\hline E7 & 0 & 0 & 0 & 1 & 0 & 2 & 0 & 0 & 0 & 0 & 0 & 0 & 0 \\
\hline E8 & 2 & 0 & 0 & 8 & 7 & 9 & 6 & 0 & 1 & 5 & 0 & 4 & 3 \\
\hline E9 & 0 & 0 & 0 & 6 & 5 & 7 & 4 & 0 & 0 & 3 & 0 & 2 & 1 \\
\hline E10 & 0 & 0 & 0 & 2 & 1 & 3 & 0 & 0 & 0 & 0 & 0 & 0 & 0 \\
\hline E11 & 3 & 1 & 0 & 9 & 8 & 10 & 7 & 0 & 2 & 6 & 0 & 5 & 4 \\
\hline E12 & 0 & 0 & 0 & 3 & 2 & 4 & 1 & 0 & 0 & 0 & 0 & 0 & 0 \\
\hline E13 & 0 & 0 & 0 & 4 & 3 & 5 & 2 & 0 & 0 & 1 & 0 & 0 & 0 \\
\hline
\end{tabular}

\begin{tabular}{|c|c|c|c|c|c|c|c|c|c|c|c|c|c|c|}
\hline \multicolumn{10}{|c|}{ A $=\mathbf{M}+\mathbf{M 2}$} \\
\hline & E1 & E2 & E3 & E4 & E5 & E6 & E7 & E8 & E9 & E10 & E11 & E12 & E13 & Sum \\
\hline E1 & 0 & 0 & 0 & 6 & 5 & 7 & 4 & 0 & 0 & 3 & 0 & 2 & 1 & 28 \\
\hline E2 & 2 & 0 & 0 & 8 & 7 & 9 & 6 & 0 & 1 & 5 & 0 & 4 & 3 & 45 \\
\hline E3 & 5 & 3 & 0 & 11 & 10 & 12 & 9 & 2 & 4 & 8 & 1 & 7 & 6 & 78 \\
\hline E4 & 0 & 0 & 0 & 0 & 0 & 1 & 0 & 0 & 0 & 0 & 0 & 0 & 0 & 1 \\
\hline E5 & 0 & 0 & 0 & 1 & 0 & 2 & 0 & 0 & 0 & 0 & 0 & 0 & 0 & 3 \\
\hline E6 & 0 & 0 & 0 & 0 & 0 & 0 & 0 & 0 & 0 & 0 & 0 & 0 & 0 & 0 \\
\hline E7 & 0 & 0 & 0 & 2 & 1 & 3 & 0 & 0 & 0 & 0 & 0 & 0 & 0 & 6 \\
\hline E8 & 3 & 1 & 0 & 9 & 8 & 10 & 7 & 0 & 2 & 6 & 0 & 5 & 4 & 55 \\
\hline E9 & 1 & 0 & 0 & 7 & 6 & 8 & 5 & 0 & 0 & 4 & 0 & 3 & 2 & 36 \\
\hline E10 & 0 & 0 & 0 & 3 & 2 & 4 & 1 & 0 & 0 & 0 & 0 & 0 & 0 & 10 \\
\hline E11 & 4 & 2 & 0 & 10 & 9 & 11 & 8 & 1 & 3 & 7 & 0 & 6 & 5 & 66 \\
\hline E12 & 0 & 0 & 0 & 4 & 3 & 5 & 2 & 0 & 0 & 1 & 0 & 0 & 0 & 15 \\
\hline E13 & 0 & 0 & 0 & 5 & 4 & 6 & 3 & 0 & 0 & 2 & 0 & 1 & 0 & 21 \\
\hline
\end{tabular}


Serkan ALTUNTAS. He received the B.S. degree in industrial engineering from Eskişehir Osmangazi University in 2006, the M.S. degree industrial engineering from Dokuz Eylül University in 2010 and the $\mathrm{PhD}$ degree in industrial engineering from the University of Gaziantep in 2014. He is currently an Assistant Professor in the Department of Industrial Engineering at Yildiz Technical University. His research interests include facility layout and technology evaluation. He has published papers in various journals, including the Total Quality Management \& Business Excellence, Technological Forecasting and Social Change, and The International Journal of Advanced Manufacturing Technology.

Türkay DERELI. He is a professor of IE Department at Gaziantep University (GAUN) and serves as the President of Iskenderun Technical University, in Turkey. He received his BSc. and MSc. in Mech. Eng. from METU and GAUN, in 1992 and 1994, respectively. He earned his PhD degree from the GAUN, Institute of Natural and Applied Sciences, in 1998. He has published numerous papers in professional academic journals and has several textbooks on CAD/CAM, IT, brand and quality management. His current research interests include: technology management, expert systems, economics, CAD/CAM, quality planning and control, TQM, agile/responsive manufacturing, engineering management, informatics and applications of artificial intelligence.

Mustafa Kemal YILMAZ. He graduated from Karadeniz Technical University, Faculty of Economics \& Administrative Sciences, and Department of Economics. He started work as a Lecturer at Ataturk University in 2001. He completed his Master degree in 2005 and his PhD in 2010. He is now an Assistant Professor at Ondokuz May1s University, Department of Business. His study area is Industrial Marketing, Service Marketing and Marketing Research. 